\title{
33. THE CONTINENTAL MARGIN OFF GALICIA AND PORTUGAL: ACOUSTICAL STRATIGRAPHY, DREDGE STRATIGRAPHY, AND STRUCTURAL EVOLUTION
}

\author{
Groupe Galice ${ }^{1,2,3}$
}

\begin{abstract}
SUMMARY
This report proposes a generalized stratigraphy and a structural history of the western Iberian margin according to the data provided by gravimetric and magnetic surveys, seismic profiles, and dredgings or coring of the sea bottom. These results are correlated with data yielded by Site 398 (DSDP Leg 47B of the IPOD Project). More detailed conclusions are found in the stratigraphic and sedimentologic report in this volume.
\end{abstract}

\section{INTRODUCTION}

\section{Geological Framework}

\section{Physiography}

The bathymetric maps ${ }^{4}$ of the Galicia Bank area (Figures 1 and 2) reveal two main physiographic units on the continental margin west of Iberia and north of the Nazaré Canyon $\left(39^{\circ} 30^{\prime} \mathrm{N}\right)$.

1) From Nazaré Canyon to the latitude of Porto, offshore from the Portugal Basin, the 40 to $50-\mathrm{km}$ wide continental shelf is linked to the Iberian Abyssal Plain by a relatively narrow continental slope. The continental slope drops down directly to depths of 4000 to 5000 meters, except where it is interrupted by the Porto Seamount at 2200 meters.

2) Farther north, all the way to Cape Finisterre, the continental shelf is about $30 \mathrm{~km}$ wide and is bounded in the east by the Hercynian basement of Galicia.

3) To the west, it is prolonged for nearly $200 \mathrm{~km}$ by a marginal plateau. This plateau comprises the large Galicia Bank, whose top is 700 meters deep, and several other seamounts (Vigo, Vasco da Gama seamounts). The Galicia Bank is separated from the shelf by an Interior Basin running in a north-south direction from the Biscay Abyssal Plain to Porto Seamount.

\footnotetext{
${ }^{1}$ Centre Océanologique de Bretagne (Centre National pour l'exploitation des Océans): J. P. Auzende, H. Jonquet, J. L. Olivet, J.-C. Sibuet, B. P. 337, 29273 Brest Cedex, France.

${ }^{2}$ Groupe d'Etude de la Marge continentale de'Université de Paris: J. L. Auxiètre, G. Boillot, J. P. Dunand, A. Mauffret, 4, Pl. Jussieu, 75230 Paris Cedex 5, France.

${ }^{3}$ Institut Français du Pétrole: O. de Charpal, V. Apostolescu, L. Montadert, 1-4 Av. de Bois-Preau, 92506 Rueil Cedex, France.

${ }^{4}$ Maps were compiled from Berthois and Brenot, 1964; Berthois, 1966; Black et al., 1964; and Laughton et al., 1975; then modified with data from recent cruises and site survey conducted by French institutions.
}

\section{GEOLOGY ON THE CONTINENT AND THE CONTINENTAL SHELF 5}

Two regions (separated near $41^{\circ} \mathrm{N}$ latitude) must be distinguished on land and on the continental shelf, as they are on the margin (Lamboy and Dupeuble, 1975; Boillot et al., 1975).

North of this parallel, the Iberian Peninsula contains no Mesozoic or Recent sediment. A large section of the Hercynian Range outcrops in this region, with Paleozoic and Precambrian rocks (Galicia province in Spain, and northern Portugal). On the shelf, a monocline of Cretaceous and Cenozoic layers dipping gently westsouthwest has a thin veneer of sediments whose age is uncertain.

South of this boundary, sediments progressively cover larger surfaces of the Hercynian country in a southerly direction into the Portugal Basin. This basin trends NNE-SSW and cuts across the Hercynian directions.

The oldest Mesozoic deposits are Triassic and consist of conglomerates, sandstones, and perhaps evaporites of limnic and lagoonal environments. The lagoonal type of environment continued to prevail in the Early Jurassic, producing dolomites and evaporites which result in the formation of diapirs (Hallam, 1971). Open marine sedimentation followed and persisted until Middle Jurassic time, with argillaceous and oolitic limestones on the continent and pelagic limestones on the shelf. After a short regression (Oxfordian), marine deposition resumed during the Late Jurassic, but with neritic and reefal characteristics developing both in the continental basin and on the shelf. This was followed by finely terrigenous deposition. At the end of the Jurassic, the sea receded from most of the basin and red clayey sandstones were deposited. The regression and deposition of clastics are related to important epeirogenic movements which have been observed in many places in western Europe. In the mid-Cretaceous (Cenomanian), an important transgression in Portugal was

5 The following authors may be referred to: Baldy, 1977; Baldy et al., 1977; Berthou, 1973; Berthou and Lauverjat, 1974; Boillot et al., 1974a, 1974b, 1975; Boillot and Capdevila, 1977; Boillot and Mougenot, 1977; Hallam, 1971; Lamboy and Dupeuble, 1975; Lamboy, 1975; Mougenot, 1976; Mouterde, 1971; Mouterde and Ruget, 1975; Musellec, 1974; Parga, 1969; Ramalho and Rey, 1975; Rey, 1975; Ruget-Perrot, 1961; Teixera, 1968; Vegas, 1975; and Wilson, 1975. 


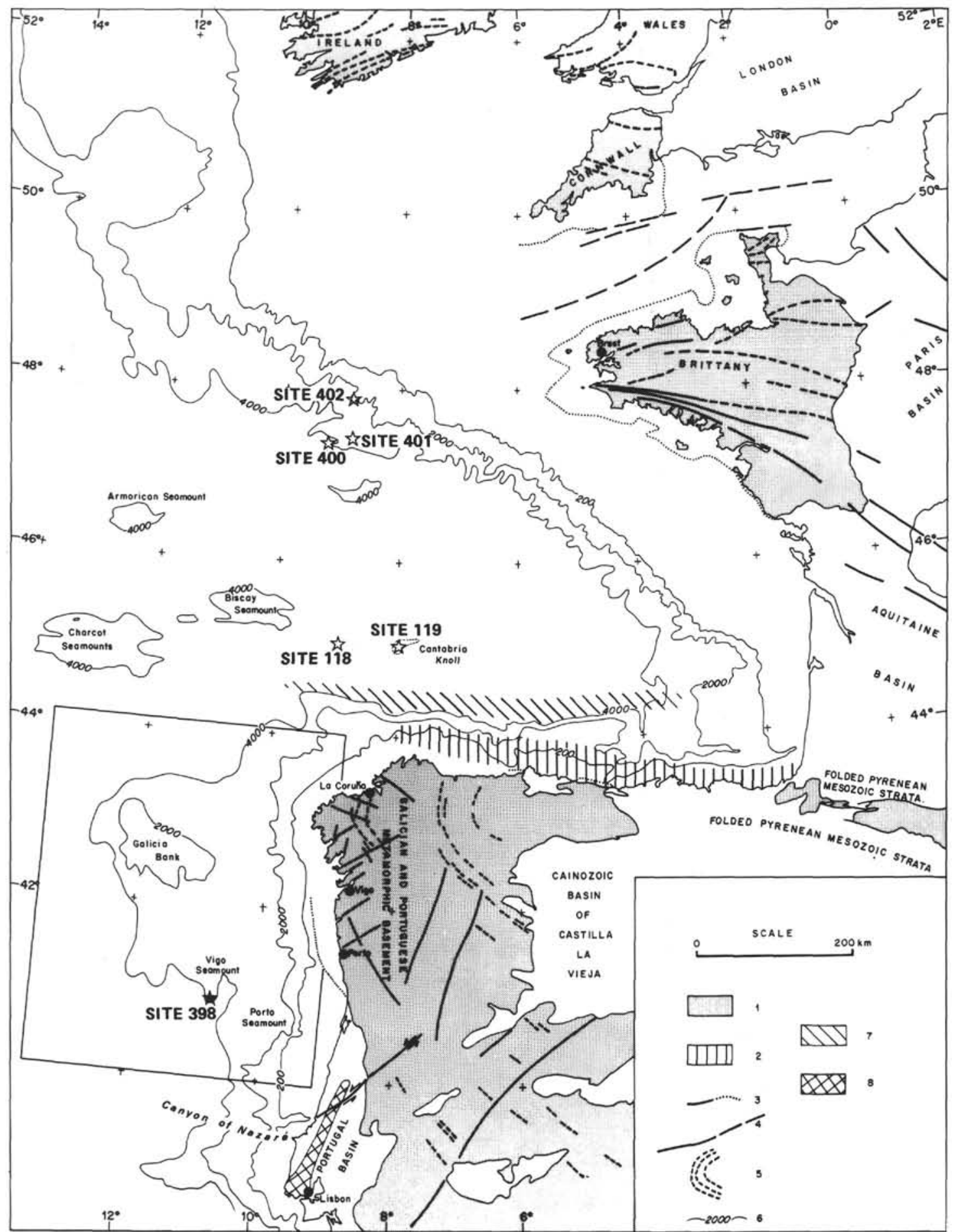

Figure 1. Generalized physiography of southwestern European coast and margin, indicating the location of the Leg 47B drilling area. (1) Hercynian Ranges and Paleozoic basins. (2) Undersea area affected by Pyrenean tectonic movements (probable extension). Blank areas inland represent Mesozoic and Cenozoic basins. (3) Boundaries of inland basins and their undersea extension. (4) Main fracture zones and faults. (5) Main Hercynian fold trends. (6) Contours of 200, 2000, and 4000meter bathymetric intervals. (7) Tectonized area on the Abyssal Plain. (8) Central Portuguese Basin. Data from large-scale onshore geological maps, maps of the English Channel and Armorican Shelf, and map of the Portuguese Shelf (in press). 


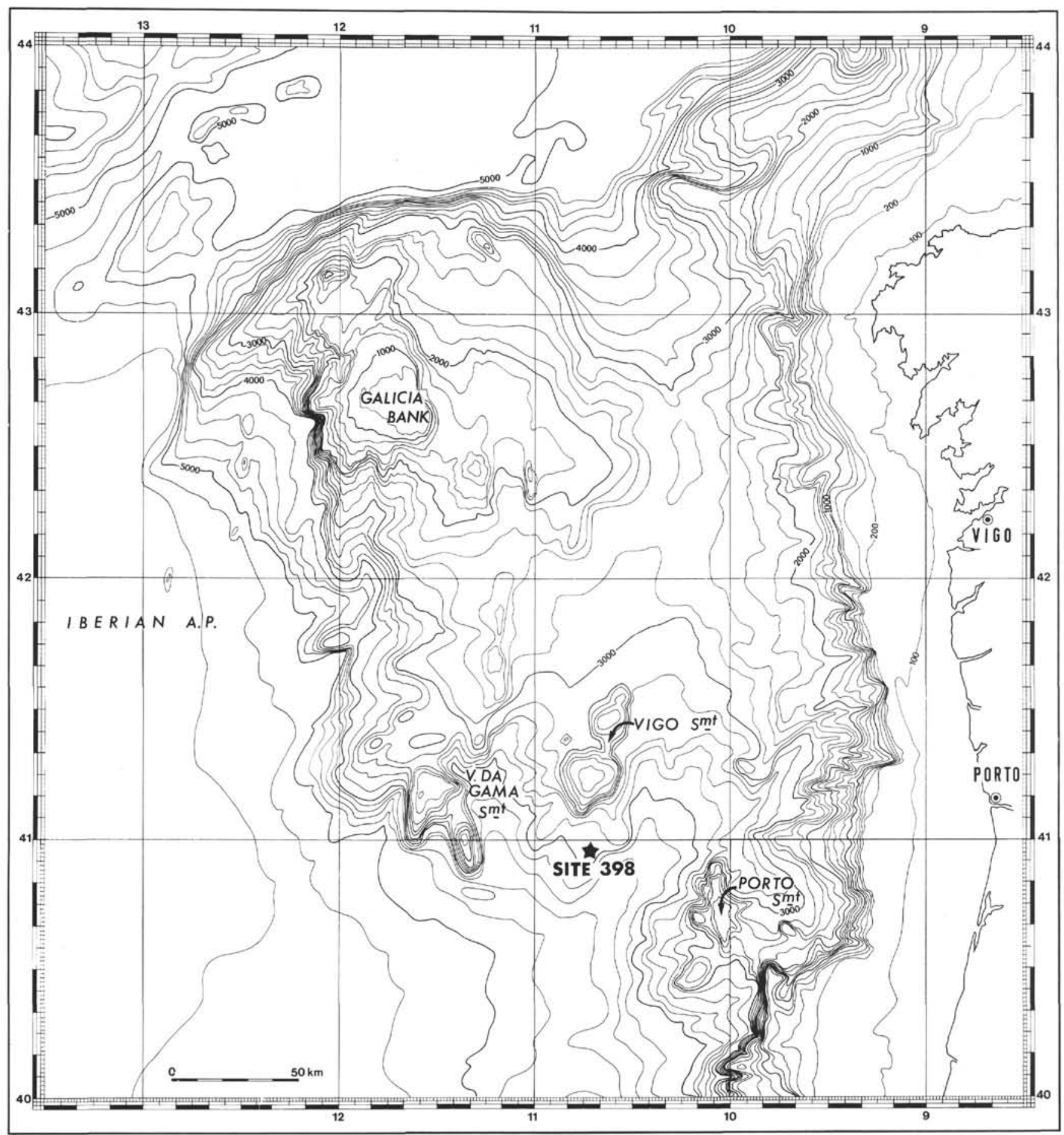

Figure 2. Bathymetric map of the western Iberian margin. Contours in corrected meters (intervals of 200 meters in the margin and 100 meters in the Abyssal Plain). Map contoured by J. L. Auxietre, J. P. Dunand, and J. R. Vanney, after data from Laughton et al. (1975) and French cruises.

as extensive as the one in the Middle Jurassic and replaced continental sedimentation with marine deposits. Afterwards, because of vertical movement of the elongated Nazare Fault, the southern part of the basin (in the Estramadura province) emerged and was covered by volcano-sedimentary layers of uncertain age (Late Cretaceous to Eocene), resting unconformably on the Cenomanian. During this time, the northern part of the basin progressively subsided and underwent alternating transgressive-regressive episodes during Late Cretaceous and Tertiary time. On the continental shelf, no identifiable Cenomanian or Turonian has been dredged, but the same differentiation seems to exist as on land. Senonian is well represented only north of Nazaré Canyon which prolongs the Nazaré Fault. The Senonian strata consist of limestones with pelagic microfauna, 
and resemble sediments which generally occur at the edge of a shelf or on top of a continental slope (Boillot et al., 1975). South of Nazaré Canyon, no Upper Cretaceous dredgings have been recovered, except for neritic Maestrichtian samples.

In the lower Cenozoic, regressive facies prevail everywhere; while inland, sedimentation is continental. On the shelf, it is characterized by shallow water deposits: microcodium limestones, benthic foraminifers, and algal limestones in the Eocene with clastic components in the Upper Eocene, which suggests continental erosion. The Neogene is transgressive and unconformable, but restricted to the outer parts of the shelf.

We should emphasize some types of deposits and geological events of widespread extention in western Europe: (a) evaporitic sediments in Triassic and Early Jurassic times, (b) marine Jurassic sequence, (c) Late Jurassic-Early Cretaceous regression and continental deposits, (d) Cenomanian transgression.

Structurally, deformation of the sedimentary series become more and more pronounced southwards. North of $41^{\circ} \mathrm{N}$ latitude, the continental shelf is a simple monocline of Cretaceous and Paleogene sediments with a $3^{\circ}$ dip towards the WSW. At $40^{\circ} \mathrm{N}$, latitude, diapiric anticlines both inland and on the shelf result from the mobilization of Triassic-Jurassic salt. Their NNE-SSW trend suggests that they were induced by a buried fault which prolongs a structural high of the same orientation.

Farther south, the ENE-WSW Nazaré structure is the most important tectonic feature of northern Portugal. It resulted from the reactivation of an ancient fault of the late Hercynian phase. We have already seen that movement along the fault during the Cretaceous separated two regions of differing deposition. It was active again during the Eocene and Neogene, probably as a reverse fault under the compressionnal stresses which affected all of Iberia (Boillot et al., 1975). Off the coast, it is prolonged by the Nazaré Canyon which cuts across the shelf and the continental slope. Faults of the same general NE-SW trend occur over the entire Hercynian basement, especially in Galicia where they control the direction of the coastal rias.

\section{Gravimetric Data}

We have compiled a gravimetric map of free-air anomalies from data collected by the Centre Océanologique de Bretagne and other institutions: the Royal Netherlands Navy, the University of Cambridge, and the Service Hydrographique et Océanographique de la Marine (Sibuet et al., in preparation).

The following four clearcut domains can be distinguished (Figure 3):

a) Galicia Bank corresponds to a strong positive anomaly which may exceed $150 \mathrm{mgal}$. The free-air gravity anomaly, corrected for the edge effect, reaches almost $100 \mathrm{mgal}$ on the Galicia Bank shoal (Sibuet and Le Pichon, 1971).

b) East of Galicia Bank, a negative anomaly outlines the Interior Basin, and especially its western border where the free-air gravity anomaly gradient is very high and corresponds to the eastern structural boundary of Galicia Bank. The major structural boundary, parallel to one of the Hercynian Fault directions, extends to the Iberian continental slope and limits the continental shelf seawards off Porto. This direction may also extend inland.

c) North of Galicia Bank, a negative gravimetric anomaly, reaching $-125 \mathrm{mgal}$ is oriented in a NE-SW direction. This anomaly extends along the northern Spanish marginal trough, in a different direction and weaker in amplitude. According to Sibuet and Le Pichon (1971) and Sibuet et al. (1971), this structure may be interpreted as an extension of a fossilized trench that was active either until the late Eocene (coincident with formation of the Pyrenees; Choukroune et al., 1973) or until the early Miocene. This structure ends north of Galicia Bank and has been considered by Le Pichon and Sibuet (1971b) to be a plate boundary extending to the northwest through the Azores-Biscay Rise as a boundary of a different type (shearing or extension).

d) West of Galicia Bank, the Iberian Abyssal Plain shows anomalies of wide extension, slightly negative, thereby excluding the presence of a trench structure similar to that North of the Iberian Peninsula.

\section{Magnetic Data}

Data collected by the Centre Océanologique de Bretagne have been combined with data collected by the Royal Netherlands Navy, the University of Cambridge, the Service Hydrographique et Oceanographique de la Marine, the Université Pierre et Marie Curie, and the Institut Français du Pétrole to draw a map of magnetic anomalies (Sibuet et al., in preparation). The tracklines are sufficiently closely spaced to draw significant magnetic anomalies. However, because the measurements were obtained during the last 15 years, the secular variation can produce errors of as much as several tens of gammas at the intersections of the profiles (Groupe Galice et al., 1976; discussion in Sibuet et al., in preparation).

Three domains can be distinguished (Figure 4) as follows:

a) The area of Galicia Bank, in its broadest sense (involving Galicia Bank itself and the north-south basin separating it from the Iberian Peninsula and the adjacent continental shelf), is characterized by magnetic anomalies of \pm 150 gammas, without any orientation. This is similar to the continental magnetic anomalies. As magnetic sources are at a depth of several kilometers below the sedimentary basin, their similarity of form and amplitude means the Galicia Bank could be of continental origin without making any assumptions as to the nature and origin of the sedimentary basin between it and the continent.

b) Between Galicia Bank and the first anomalies of the northeast Atlantic ( $A-34$, dated 78 m.y.B.P. and late Santonian according to van Hinte, 1976), a series of positive and negative anomalies of \pm 150 gammas occur with a spacing less than that in the continental domain. Their size and spacing are close to those of the 


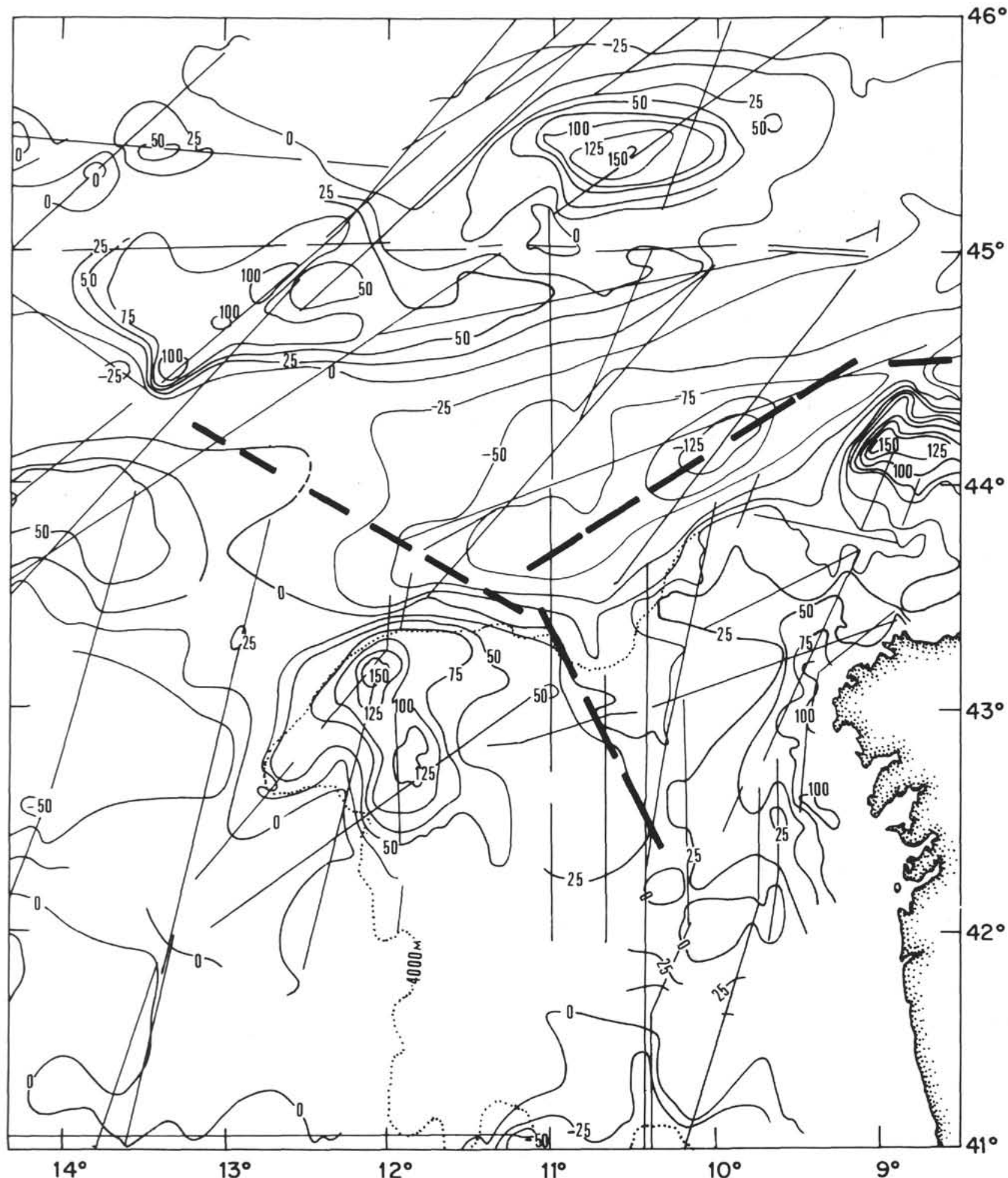

Figure 3. Free-air gravimetric anomaly map of northern Iberian margin and southwestern Bay of Biscay. Contour interval is 25 milligals; continuous lines represent tracklines; heavy dashed lines are the limits of domains; explanation in text (after Sibuet et al., in preparation). 


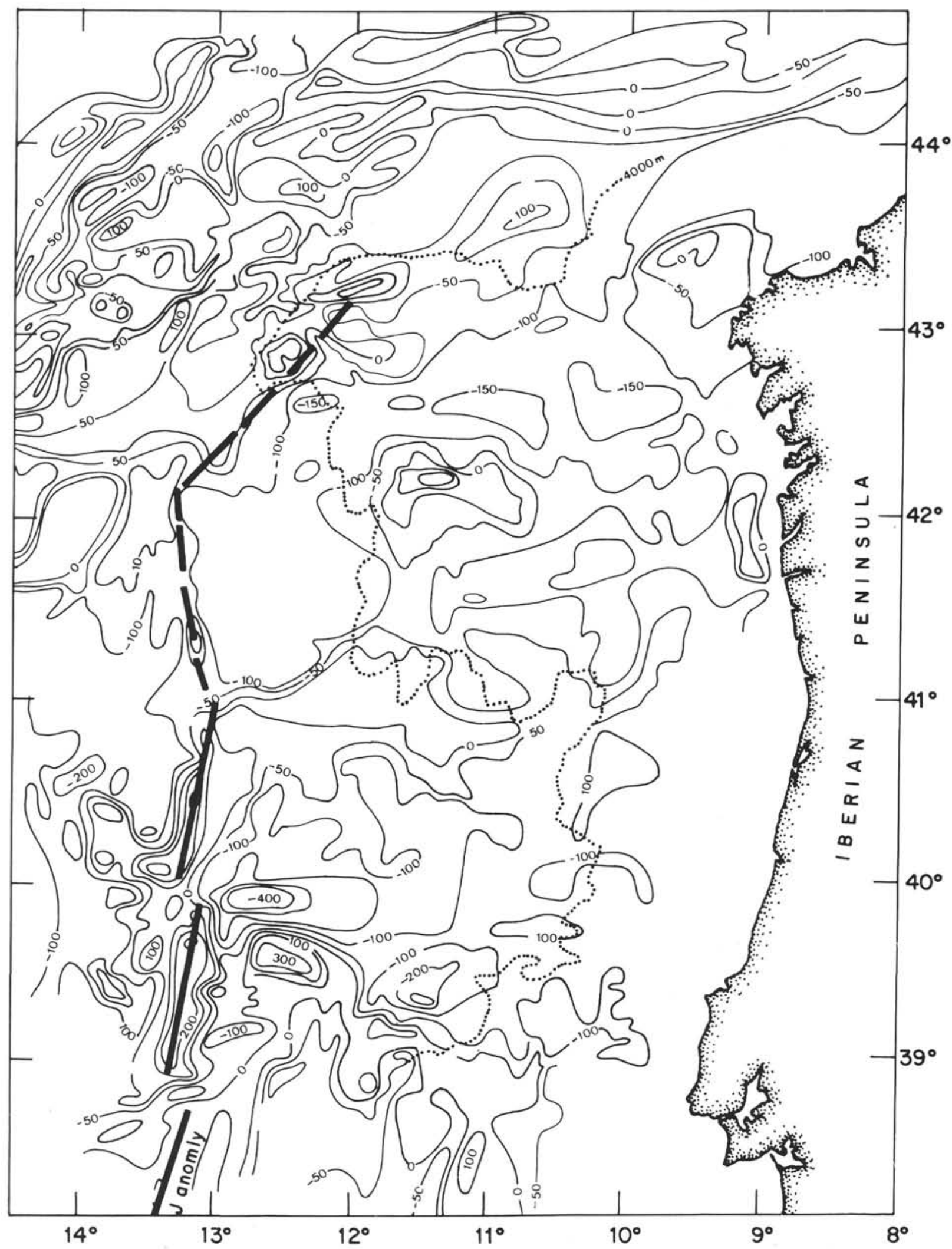

Figure 4. Magnetic anomaly map of Iberian margin. Contour interval is 50 gammas; heavy solid lines represent $\mathrm{J}$ anomaly; heavy dashed line is the western boundary of the Cretaceous magnetic quiet zone lafter Sibuet et al., in preparation). 
Cretaceous quiet zone west of northern Africa (Hayes and Rabinowitz, 1975). These anomalies have a general NE-SW orientation. It is difficult to correlate these anomalies with Keathley's Sequence because they are too short. If this zone corresponds to the Cretaceous quiet sequence, it is interesting to note that magnetic correlations exist over short distances (of $100 \mathrm{~km}$ maximum). Such correlations can also be observed on the profiles of Hayes and Rabinowitz (1975).

The Cretaceous quiet magnetic zone (Figure 4) is identified with the following: (1) the Tore-Madeira Rise which corresponds to anomaly $J$ (Pitman and Talwani, 1972; Olivet et al., 1976a; Rabinowitz et al., 1979); (2) a positive anomaly which prolongs the Tore-Madeira Rise until $41^{\circ} \mathrm{N}$ latitude and which could correspond to anomaly $M 0$; and (3) a line which separates two distinct magnetic provinces and bounds the northwest corner of Galicia Bank.

Anomaly $J$ has been identified with anomaly $M 0$ M1 (Rabinowitz et al., 1979) and dated late Aptian (Leg 53, Francheteau, personal communication; van Hinte, 1976). If these assumptions are correct, oceanic crust younger than late Aptian is present west of this boundary. This does not mean that typical oceanic crust older than late Aptian is absent to the east of this boundary.

c) North of Galicia Bank, the Cretaceous quiet magnetic zone disappears at $44^{\circ} \mathrm{N}$ latitude against east-west magnetic trends of high amplitude ( 300 gammas) associated with North and South Charcot seamounts and Biscay Seamount.

\section{STRATIGRAPHY}

This section uses two sources of data and attempts correlation between them. The first source is the acoustic stratigraphy interpreted from numerous seismic profiles existing in the Galicia Bank and Vigo Seamount area (Figure 5). The second source is data from dredge and core samples, and including samples from DSDP Site 398.

When the IPOD project in the Galicia area was initiated, published regional information was scarce (Black et al., 1964; Funnel and Smith, 1968; Montadert et al., 1974). The three French institutions interested in the program (Centre Océanologique de Bretagne-CNEXO, the University of Paris "Groupe d'Etude de la Marge Continentale," and Institut Français du Pétrole) joined the "Galicia Group." Three cruises (Albatlante, Lusitanie 74, Tripode) were carried out on the western Iberian continental margin before IFP undertook the site survey. After Site 398 was drilled, the Hespérides cruise added to previous information with $850 \mathrm{~km}$ of seismics and through dredgings on Vigo Seamount, Vasco da Gama Seamount, and the Galicia Bank. Overall, we used $8350 \mathrm{~km}$ of reflection seismics and 20 large samplings of outcropping rocks. Table 1 summarizes these operations.

\section{Acoustic Stratigraphy}

The seismic sections generally show a layered sedimentary sequence covering an irregular "mountain- ous" diffractive acoustic basement whose compressional wave velocities are higher than velocities in the sediments.

The sedimentary cover infills the topographic lows and blankets the highs of the so-called acoustic basement, as can be seen on Figure 6. The isopach map of the entire sedimentary cover (Figure 7), when compared to the bathymetric map (Figure 2), shows that present morphological depressions correspond to sedimentary basins with thick deposits. Similary, seamounts and banks are generally places of thin and incomplete deposits. An exception is Vigo Seamount whose central hollow is infilled by a thick sedimentary sequence. Therefore, there are permanent structural features in the west Iberian margin and we meet again the four physiographic units previously described, i.e., the continental slope, the Interior Basin, the Galicia Bank, and the Iberian Abyssal Plain.

The sedimentary cover comprises four main units, numbered Formations 1 to 4 from the sea floor downward. The first three correspond with Units 1 to 3 previously distinguished in the Bay of Biscay and on the Iberian margin (Montadert et al., 1971; Montadert and Winnock, 1971).

The basement and formations are described in their stratigraphic order, then unusual features, sedimentology, and sound velocity are discussed.

\section{Acoustic Basement}

Acoustic basement is generally diffractive and its structure is not always easily identifiable. Its upper surface is irregular and shows strong relief, either as broad undulations or as sharp crests constituting buried heights. Some of the heights may pierce the sea bottom and outcrop (Figure 6). On the continental slope and on the sides of most prominent reliefs (such as Galicia Bank), the basement seems to be divided in blocks forming a steplike pattern. In the western part of the margin, acute crests and strongly dipping layers in the basement suggest that the crests are part of tilted faulted blocks (Figure 6, in profile GP 11). Such features typify passive continental margins. We observed that several highs were topped by perfectly flat surfaces covered by a thin sedimentary blanket, e.g., Galicia Bank, and other reliefs to the southwest of Galicia Bank and northwest of Vigo Seamount. The basement of Vigo Seamount itself is flat in some parts, probably as a result of erosion.

In some cases, the basement is bedded and its layering is strongly unconformable beneath the top surface. West of Galicia Bank, the internal basement reflectors seem to be parts of folds with anticlines and synclines. The age (Paleozoic or Mesozoic) of these east-west oriented structures is speculative; however, they were formed prior to the rifting of the margin.

\section{Formation 4}

The first sequence encountered above the diffractive acoustic basement is a moderately to strongly layered formation, often distinguished from overlying Formation 3 by a strong reflector (Figure $8 \mathrm{~B}$ and C). For- 


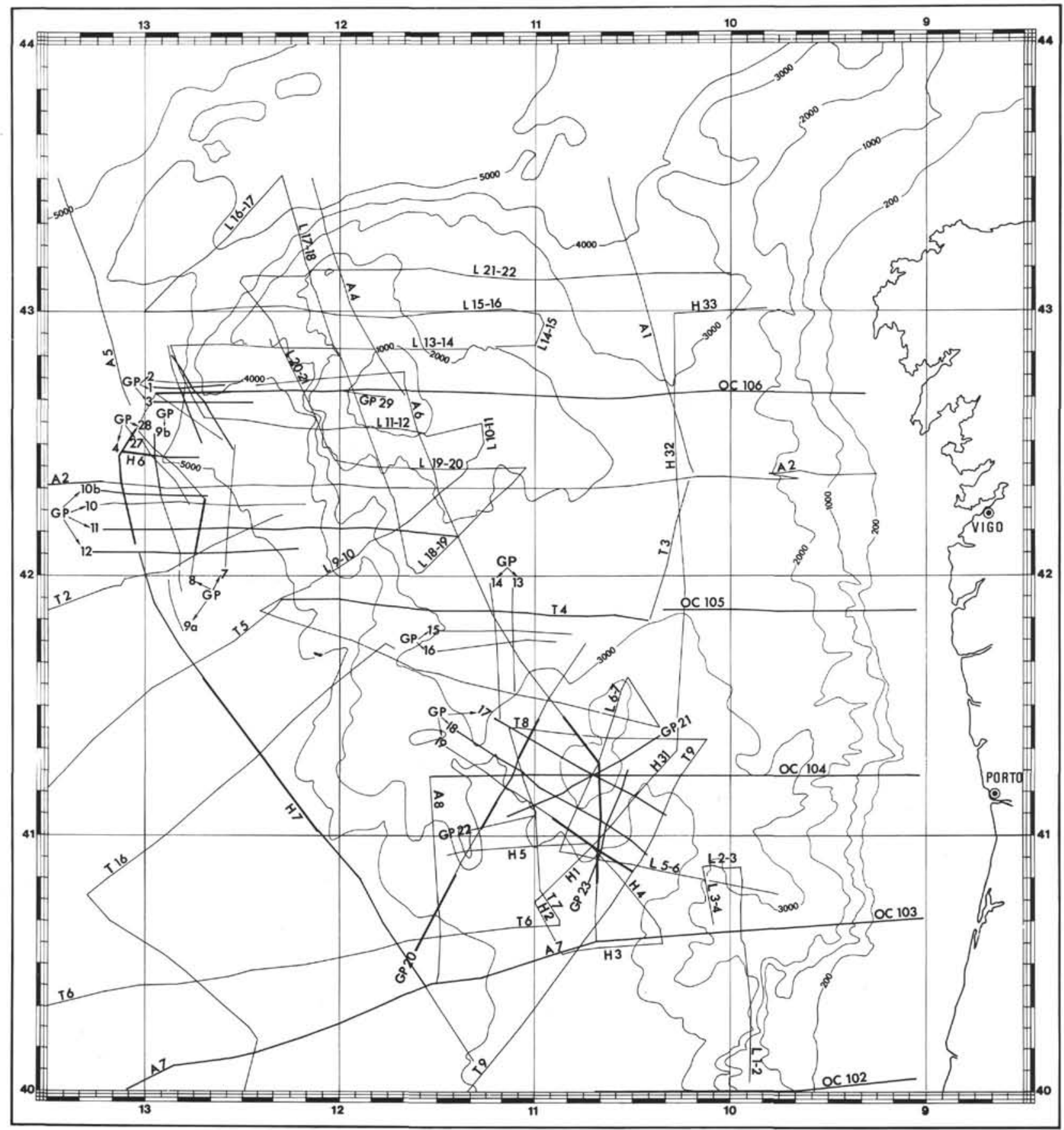

Figure 5. Location map of the seismic profiles in the Leg 47B area. Heavy lines indicate profiles used for our figures.

mation 4 infills narrow troughs between horsts or tilted blocks, and its deposition must have taken place in a structurally and morphologically differentiated environment with strong relief. Layering is conformable with the structural top of the basement in the lowest parts of the troughs. However, it becomes less and less inclined upwards and is nearly flat at the top of the formation. This clearly indicates that sedimentation occurred during tilting of the basement blocks, and trended toward horizontal layering during subsidence. Considerable differences of thickness result from this configuration (west of Profile OC 104, Figure 6). Where it is thin, Formation 4 is not easily distinguished from the strong reflectors at the top of acoustic basement.

\section{Formation 3}

Formation 3 is a generally transparent or slightly layered sequence which infills depressions or troughs between horsts and tilted blocks. This deposition behavior is similar to Formation 4, but differs in having 
TABLE 1

Summary of Stratigraphic Investigative Operations in the Continental Margin off Galicia and Portugal, Undertaken Prior to and After Drilling Site 398

\begin{tabular}{|c|c|c|c|c|c|c|}
\hline Cruise & Year & Institution & $\begin{array}{l}\text { Seismic Route } \\
(\mathrm{km})\end{array}$ & $\begin{array}{l}\text { Seismic Source } \\
\text { and Processing }\end{array}$ & $\begin{array}{l}\text { Dredging and } \\
\text { Coring } \\
\text { Successful }\end{array}$ & Publications \\
\hline R.S.S. DISCOVERY II & 1958 & I.O.S. ${ }^{\mathrm{a}}$ & - & - & 4 & $\begin{array}{l}\text { Black et al., } 1964 \\
\text { Funnel and Smith, } 1968\end{array}$ \\
\hline $\begin{array}{l}\text { Galice-Portugal } \\
\text { profiles OC } 102 \text { to } 106\end{array}$ & 1969 & $\mathrm{IFP}^{\mathrm{b}}-\mathrm{SNPA}{ }^{\mathrm{c}}$ & 850 & $\begin{array}{l}\text { Flexotir multichannel } \\
\text { X3, processed }\end{array}$ & & Montadert et al., 1974 \\
\hline $\begin{array}{l}\text { Albatlante, profiles A, } \\
\text { A } 1 \text { to } \mathrm{A} 10\end{array}$ & 1974 & C.O.B. ${ }^{\mathrm{d}}$ & 1500 & Water-gun monotrace & 5 & Dupeuble et al., 1976 \\
\hline $\begin{array}{l}\text { Lusitanie, profiles L, } \\
\text { L1 to L } 22\end{array}$ & 1974 & G.E.M.C. ${ }^{\mathrm{e}}$ & 1650 & Airgun monotrace & 4 & Dupeuble et al., 1976 \\
\hline $\begin{array}{l}\text { Tripode, profiles } \mathrm{T} 1 \text { to } \\
\mathrm{T} 9, \mathrm{~T} 15 \text { and } \mathrm{T} 16\end{array}$ & 1975 & $\begin{array}{l}\text { Galicia-Group }{ }^{f} \\
\text { operator GEMC } \\
+ \text { COB }\end{array}$ & 1800 & Water-gun monotrace & & Unpublished \\
\hline $\begin{array}{l}\text { Galice-Portugal } \\
\text { (Site Survey) } \\
\text { profiles GP1 to GP23, } \\
\text { GP26 to GP29 }\end{array}$ & 1975 & $\begin{array}{l}\text { Galicia-Group } \\
\text { operator IFP }\end{array}$ & 1700 & $\begin{array}{l}\text { Flexichoc multichannel } \\
\text { X } 6 \text { and X } 24,535 \mathrm{~km} \\
\text { processed by IFP and } \\
\text { SNPA }\end{array}$ & & Unpublished \\
\hline $\begin{array}{l}\text { Hesperides, profiles } \mathrm{H} \text {, } \\
\mathrm{H} 1 \text { to } \mathrm{H} 7, \mathrm{H} 31 \text { to } \mathrm{H} 33\end{array}$ & 1976 & G.E.M.C. & $\frac{850}{8350}$ & Airgun monotrace & $\begin{array}{r}7 \\
-\overline{20}\end{array}$ & $\begin{array}{l}\text { Unpublished and } \\
\text { Dupeuble et al., } 1977\end{array}$ \\
\hline
\end{tabular}

${ }_{\mathrm{b}}^{\mathrm{a}}$ Institute of Oceanographic Sciences, Wormley.

$\mathrm{b}$ Institut F rançais du Pétrole, Rueil-Malmaison.

cociété Nationale des Pétroles d'Aquitaine, Pau.

Centre Océanologique de Bretagne, Brest.

'Groupe d'Etudes de la Marge Continentale,

Université Pierre et Marie Curie, Paris.

${ }^{f}$ C.O.B. + I.F.P. + G.E.M.C.

less inclined bedding. Dips appear to be only the consequence of deposition on an irregular surface and not of structural deformation. A good example of inclined sedimentary dips is the fan-like deposit seen on Figure 9C which may be interpreted either as scree at the foot of Vasco da Gama Seamount or as current transport accumulation on the "lee" side of this seamount. Deposition of Formation 3 has resulted in significant, but incomplete, leveling of the topography. Many highs are completely buried, but Formation 3 may be missing on structural crests or is represented by thin deposits invisible on seismic sections. The most prominent relief features, which appear much higher than the top of Formation 3, may have been reactivated afterwards.

\section{Formation 2}

As a consequence of the leveling action of Formation 3 sedimentation, Formation 2 seems to have deposited often on almost flat topography. It may blanket basement areas which previously received no sediments (Figure 6, center of profile OC 106). Formation 2 is a layered sequence with several good reflectors (Figure 8 ), especially to the east and south of the margin. Formation 2 is layered at the top in the west and southwest, and bounded in its lowermost part by one or more strong reflectors; the middle part is layered only weakly. Its well-defined base frequently lies in slight unconformity on Formation 3; a ragged or "wavy" boundary is common. Bedding is generally flat or con- formable with the lower boundary. Profiles clearly show large-scale inclined bedding in Formation 2 in the interior basin. In the southeastern part of the margin (along profile T 9), several strong reflectors seem to correspond to layers prograding southward; each prograding unit averages $30 \mathrm{~km}$ in length.

\section{Formation 1}

Formation 1 comprises an upper Member 1a, which is widespread over the entire area, and a lower Member $1 \mathrm{~b}$ of more restricted extent. Member 1a (Figures $8 \mathrm{~B}$ and $9 \mathrm{~A}$ ) is everywhere acoustically transparent or slightly and regularly layered. It drapes the topography in formerly tectonically active zones, whereas its internal layering and top surface (forming the present sea bottom) are flat and horizontal in abyssal plains.

In some regions, a lower Member $1 \mathrm{~b}$ can be distinguished from Member 1a. It is heavily layered and only can be differentiated from the underlying Formation 2 where a well-marked angular unconformity exists between these two units. Moderate movements distorted Formation 2; afterwards, the material of Member $1 \mathrm{~b}$, probably transported by deep turbiditic currents, replenished the lowest parts of the deformed sea bottom, so that the horizontal layers of $1 \mathrm{~b}$ onlap Formation 2 and cover the relief (Figure 6, upper left).

Member $1 \mathrm{~b}$ is well represented in the abyssal western and southwestern parts of the margin; in the southern part of the Iberian Abyssal Plain it may be more 


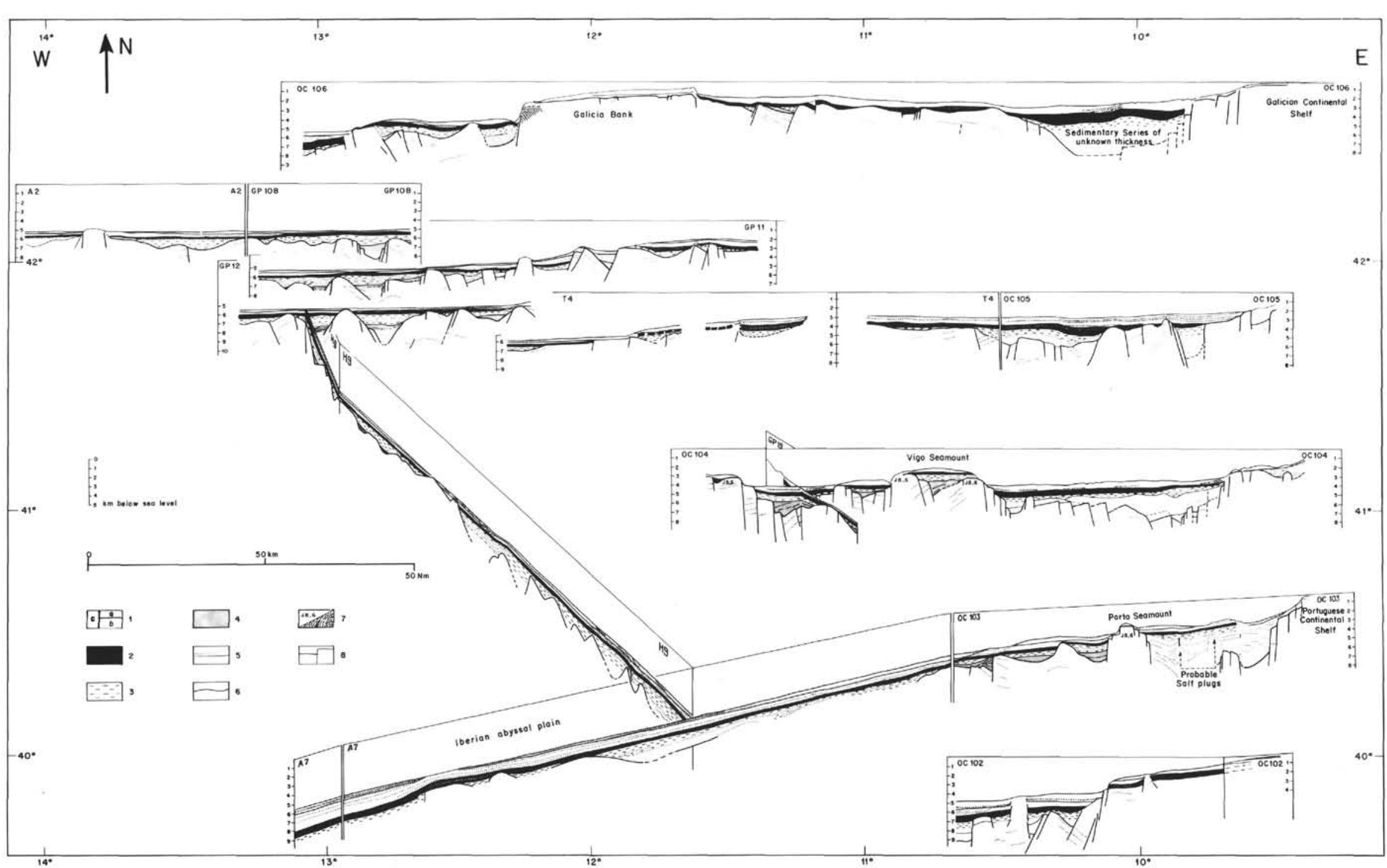

Figure 6. Depth sections across the Galician-Portuguese margin. Sections are constructed with the help of sound velocities derived from processing of seismic data. For unprocessed profiles, approximate velocity laws from nearest processed profiles were used. Depth below sea level is expressed in kilometers, vertical exaggeration is $2.5 X$. North-south spacing of profiles is compressed of about a 1.7 factor if compared to the east-west scale. (1) Formation 1 ( $a=$ upper member, $b$ $=$ lower member, $c=$ undifferentiated); (2) Formation 2; (3) Formation 3; (4) Formation 4; (5) seismic reflectors (solid lines = boundaries between formations, dotted lines = other sedimentary reflectors); (6) top of acoustic basement; (7) acoustic basement rocks collected from dredging. J8-6, Upper Jurassic (Kimmeridgian to Portlandian), m. metamorphic and crystalline; (8) Faults. 


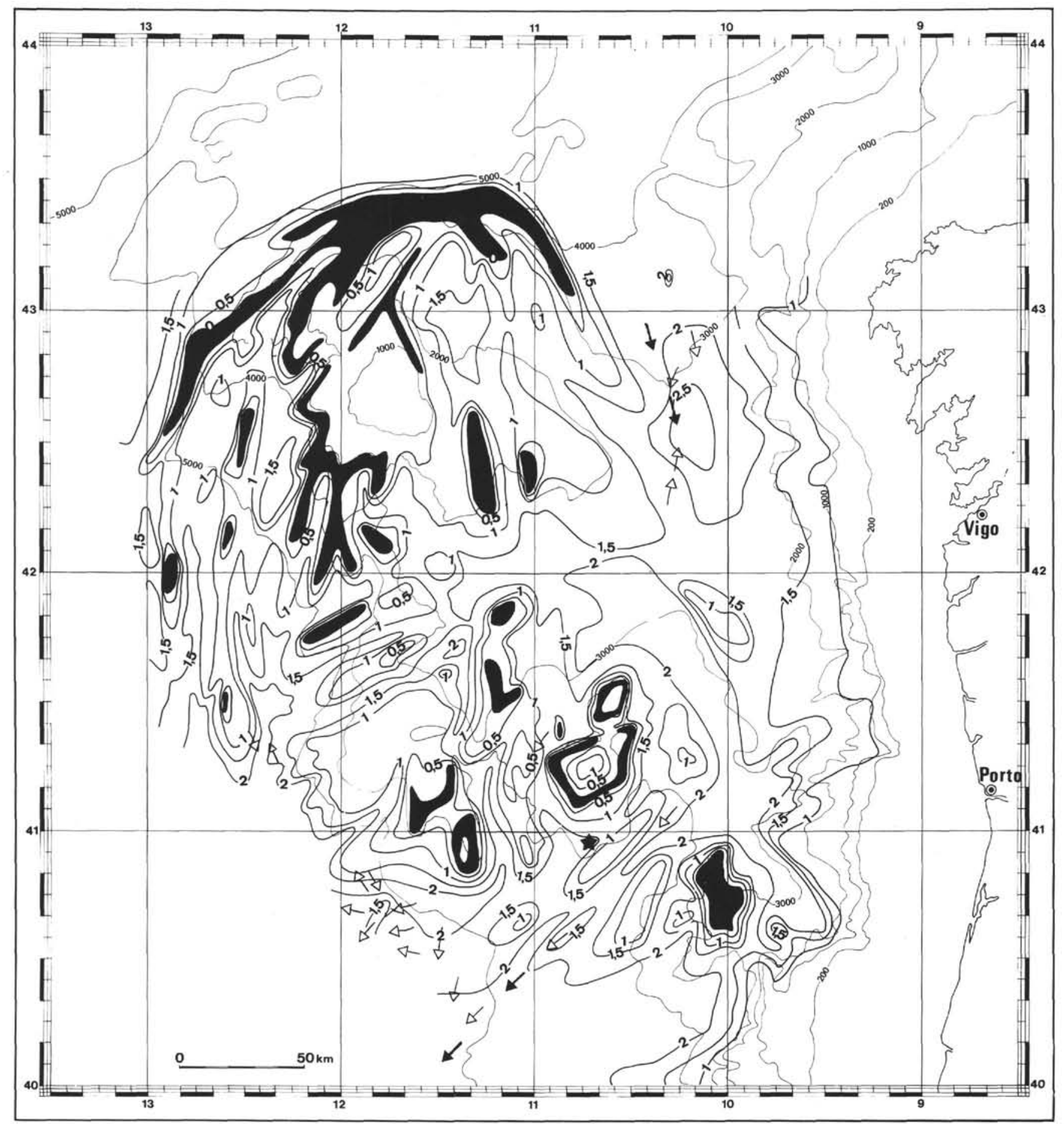

Figure 7. Time-isopach map of sedimentary cover. Contour intervals are in half-second of two-way sound travel time. Striped areas indicate little or no sediment is present above acoustic basement. Arrows show directions of bottom current inferred from sedimentary features seen on seismic profiles; black arrows = currents in Formation 2 , empty arrows $=$ currents in Formation 1.

than 1500 meters thick. It is also possible that sediments contemporaneous with Member $\mathrm{lb}$ are present in the Interior Basin, but they cannot be separated from la.

Formation 1 generally is horizontally bedded, but inclined bedding is frequent in the axis of Interior $\mathrm{Ba}$ - sin, between Vigo and Porto seamounts, and in the southern Iberian Abyssal Plain (Figure 9A).

\section{Other Sedimentary Deposits}

Besides the above-mentioned formations, some seismic profiles below Formation 2 show thick series 

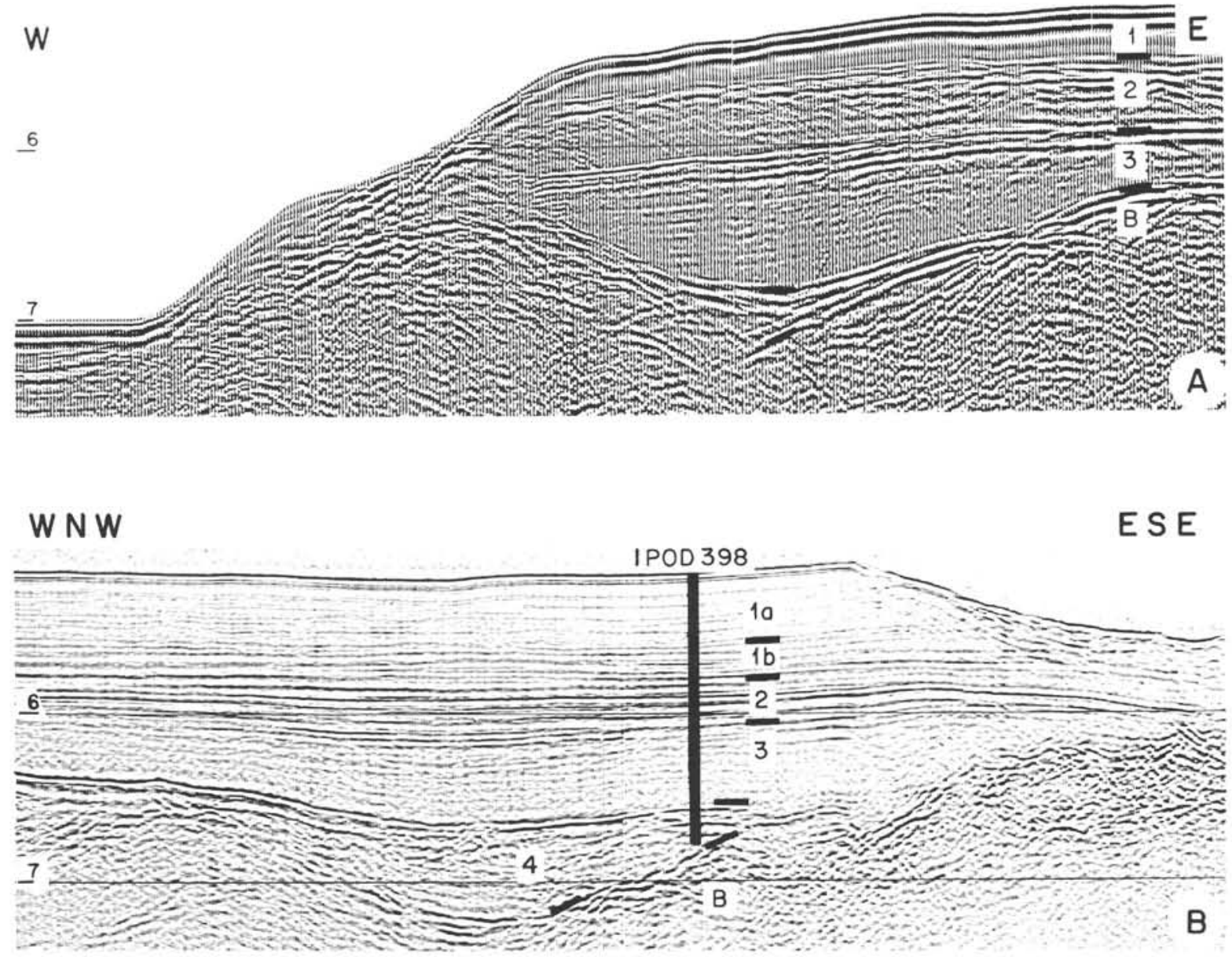

S

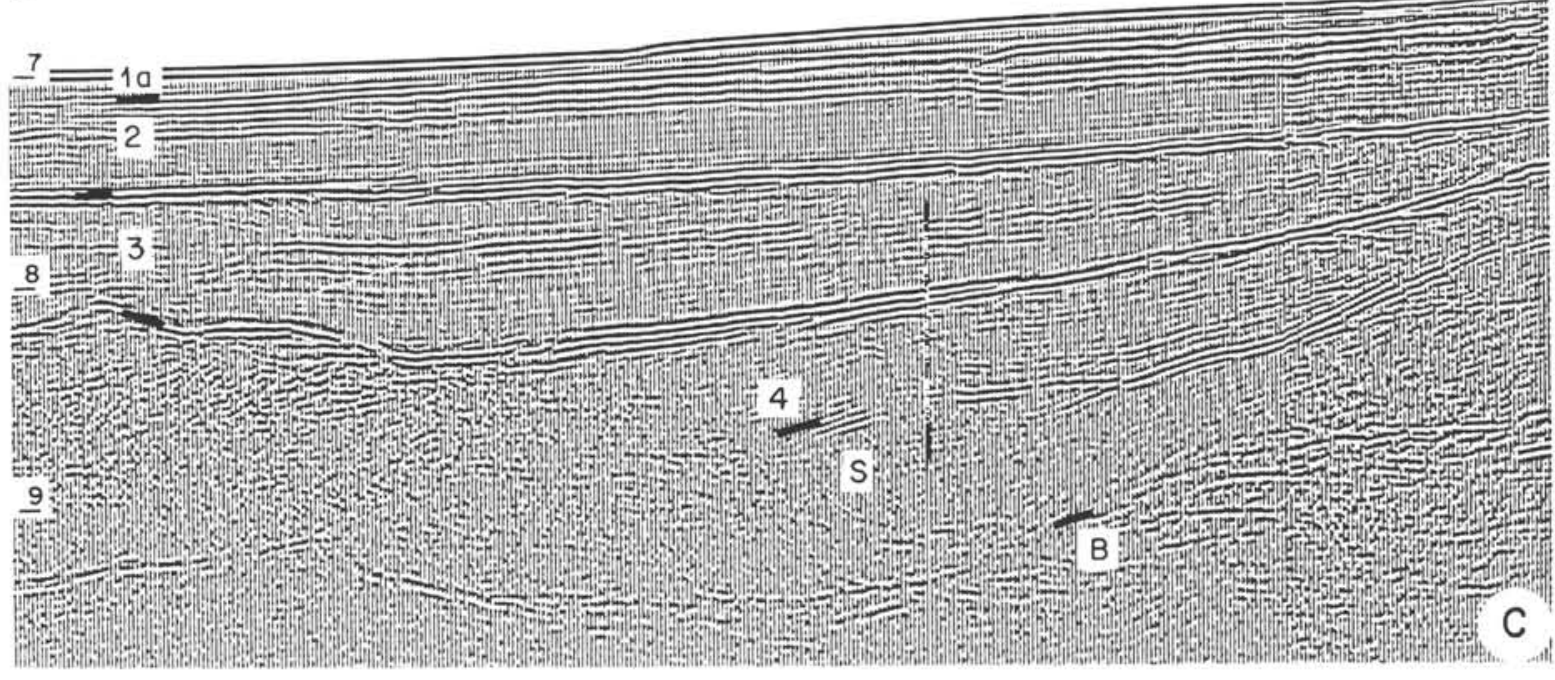

Figure 8. Acoustic formations. (A) Abyssal plateau west of Galicia Bank (OC 106). (B) Profile GP 19 in Site 398 area. Note erosional feature on right of the figure. (C) Sediments in trough between two tilted blocks (GP 08 in Iberian Abyssal Plain). Thickness of sediments is more than two seconds. Discontinuities between 2 and 3 , as well as 3 and 4 appear very clearly; strata in Formations 3 and 4 are dipping. 1, 2, 3, and $4=$ Formation numbers; $S=$ sediments lower than Formation $4 ; B=$ acoustic basement. Vertical scale in seconds of two-way travel time. 
SW

NE
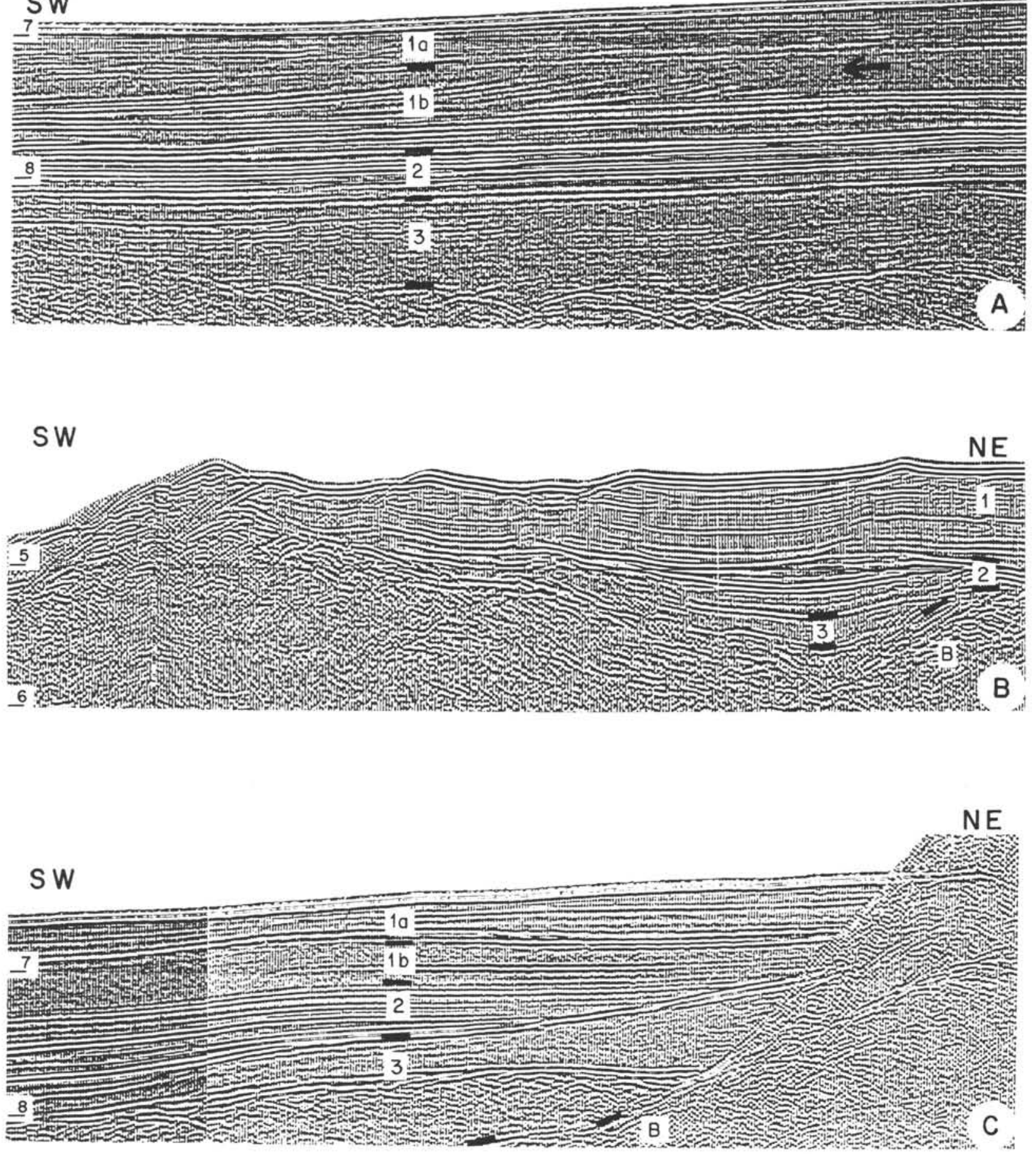

Figure 9. Sedimentary features, resulting from current transport. (A) Inclined bedding south of Vasco da Gama Seamount (profile GP 20). (B) Ridges with inclined bedding west of Vigo Seamount (GP 20). (C) Sedimentary prism at foot of Vasco da Gama Seamount (GP 20). 
which we could not correlate with some other formations. They infill narrow basins isolated from other regions by horsts. Such basins are apparent on the continental slope (Figure 6, eastern part of profiles OC 102, 103 , and 105) and in some parts of the Interior Basin. They may contain diapir-like structures (OC 102 and 103, Montadert et al., 1974), which is not surprising since salt basins and structures are known inland. We reasonably can assume that the thick series represent the Mesozoic down to the Triassic and Lower Jurassic. Such basins may reflect the vestiges of initial rifting with a restricted marine environment (Auffret et al., 1976).

Other thick sedimentary sequences occur locally west of Galicia Bank and in the Iberian Abyssal Plain. They may comprise the lower Mesozoic series, but we lack direct evidence for that assumption.

\section{Sedimentary and Erosional Features; Unconformities}

Inclined bedding is seen in Formation 1 and occasionally in Formation 2 on profiles A 1, H 32, T 9, A 7, and GP 20 (Figure 9A, OC 102 and H9). This unconformity occurs in the Interior Basin, especially around its southern outlet between Vigo and Porto seamounts. Large-scale progradation is observed to the south of Vigo Seamount. These sedimentary features indicate a general sediment transport direction trending southwestward from the Interior Basin to the Iberian Abyssal Plain. In the Interior Basin itself, there also may be reverse south-north currents. In the Iberian Abyssal Plain, currents diverge and spread laterally in a complex pattern. Current deposition is ongoing today and appears to have been a long-persisting feature on the southern part of the margin. Current deposition, which seems first recorded in Formation 2 (where some progradation appears) is conspicuous in Unit 1 (inclined bedding). Giant sedimentary ridges or "ripples" may be seen west of Vigo Seamount (Figure 9B) in the "strait" between Vasco da Gama and Vigo seamounts. Currents may have been strong enough to prevent deposition or removal of previously deposited formations. Formation 1 is almost completely missing on the sides or "banks" of the channel between Vigo and Porto seamounts, whereas its bottom is infilled with prograding sediments.

Less conspicuous erosional features are seen elsewhere, mainly at the boundaries between Formations 1 and 2 and Formations 2 and 3. Part of Formation 2 may be eroded from the top of flexures in the abyssal plain west of Galicia Bank, and on tilted blocks east of the same bank. More important and widespread erosion occurs at the top of Formation 3, which is conspicuous when the beds are slightly deformed (as in Figure $8 \mathrm{~B}$. It seems that, either resulting from differential compaction or slight tectonic movements, the top of Formation 3 was deformed slightly and the highs were eroded. In other cases, the boundary between Formations 2 and 3 is ragged. Erosion at the top of Formations 3 and 2 is dated, respectively, as Cenomanian and latest Eocene. In the "strait" between Vigo and
Porto seamounts, erosional processes have been continuous at least since Eocene time.

\section{Sound Velocity in the Formations}

About 350 compressional wave velocities were calculated for the construction of depth profiles, for the purpose of obtaining geological sections with minimal scale deformation. To this must be added 260 velocity values solely for the study of the Site 398 area. These velocity values were obtained by the Dix relation from rms velocity spectra after processing of seismic records. It was soon obvious that velocity characteristics of different formations were of stratigraphic value. We retained 450 values as suitable for constructing mean velocity curves for different sites.

When a sufficient number of measurements provides a statistical basis (Figure 10B), velocity values appear well grouped in Formations 1 and 2. They are more dispersed in Formation 3, and widely scattered in Formation 4 and the basement probably because increasing depth and dip of the layers make the method inaccurate. Figures $10 \mathrm{~A}$ and $\mathrm{B}$ show the result of the representation of mean formation velocities as a function of mean formation depth (or mean formation two-way time delay). It is seen that the increase of velocity with depth is not regular. Velocity rises in Formations 1 and $2(1.7 \mathrm{~km} / \mathrm{sec}$ to $2.5 \mathrm{~km} / \mathrm{sec})$; a relative stagnation of velocity is observed in Formation 3 and often in the lowest part of Formation 2 (around $2.5 \mathrm{~km} / \mathrm{sec}$ ). A strong increase occurs in Formation 4 ( 2.5 to $3.5 \mathrm{~km} /$ $\mathrm{sec})$. In acoustic basement, sound velocity is $4 \mathrm{~km} /$ sec. This velocity profile immediately suggests that velocity is related not only to the burial depth of sediments, but also to some lithological characteristic of Formation 3. This Formation is the equivalent of the "black shales" (i.e., Units 4A and 4B of Site 398). DSDP shipboard measurements at Hole 398D showed a break in the increase of values (velocity, density) against depth in the interval between reflectors Yellow 1 and Orange (an interval corresponding to low or zero carbonate content).

\section{Stratigraphy From Core and Dredge Samples}

Numerous samples from Vigo, Porto, and Galicia seamounts and surrounding relief allow us to construct a regional stratigraphic sequence (Black et al., 1964; Funnel and Smith, 1968; Dupeuble et al., 1976, 1977; unpublished data of the Hespérides cruise, 1976) and to identify (to a certain extent) Formations 1 to 4 (observed on reflection seismics) and acoustic basement (Figure 11).

\section{Acoustic Basement}

In general, these rocks belong to the pre-Mesozoic substratum of the margin (Plutonic or metamorphic rocks of Paleozoic or Precambrian age). On several occasions we also collected samples of neritic limestones of Late Jurassic or Early Cretaceous age from outcrop zones of acoustic basement. It is therefore possible that in some cases, these fractured rocks with reefal facies 
react as diffractory bodies and correspond to a part of the acoustic basement.

\section{Mesozoic Cover}

The oldest Mesozoic strata sampled are of Late Jurassic and early Cretaceous age (Vigo, Porto, and Vasco da Gama seamounts). These are shallow-water bioclastic limestone and Calpionella pelagic micrites (Dupeuble et al., 1976, 1977). The present west Iberian margin therefore occupies an area which, at the end of Jurassic time, was an open sea continental shelf area linked to the Mesogea and the Bay of Biscay (Boillot et al., 1971a,b; Durand-Delga, 1973; Pastouret et al., 1974). Depending on where collected, the samples of Late Jurassic-Early Cretaceous age represent either acoustic basement or perhaps Formation 4.

We collected Upper Cretaceous rocks from Galicia and Vigo seamounts. They are generally marl with a pelagic microfauna (Funnel and Smith, 1968); Dupeuble et al., 1976). From Galicia Bank, however, Black et al. (1964) collected very shallow water bioclastic limestones which they believed were latest Cretaceous or Paleocene. It therefore seems that during the Late Cretaceous the west Iberian margin had already undergone a strong subsidence, except for Galicia Bank which probably was a slightly submerged shoal. In each case, the Upper Cretaceous samples were collected from outcrop zones of Formation 2.

\section{Cenozoic Blanket}

The samples from this period are all pelagic: Paleocene from Vigo Seamount, Oligocene from Galicia Bank, and Miocene from the Vigo Seamount area. Additionally, Pleistocene to Recent samples were taken (Dupeuble et al., 1976). The Neogene samples belong to Formation 1. From this stratigraphic evidence, Dupeuble et al. (1976) deduced that the west Iberian margin separated from the continental plateau in latest Jurassic or earliest Cretaceous time and underwent subsidence. It is possible, however, that Galicia Bank escaped the subsidence experienced in neighboring areas and continued in the neritic domain, at least until the beginning of the Cenozoic (see Structural Evolution During the Cenozoic, this report).

\section{Correlations}

Correlation between regional basins and Site 398 rests on seismic facies analogy and on layer-to-layer or "direct" correlation at intersections of profiles. The latter avoids facies variations. Difficulties were encountered near Site 398, where topographic conditions and synsedimentary erosion prevent a direct layer-to-layer correlation. Correlation with the Interior Basin was also poor. However, good facies analogy exists among Site 398, the Interior Basin, and the Iberian Abyssal Plain, where correlation is easy with the region west of Galicia Bank. No correlation was attempted with the surficial sedimentary formations of Galicia Bank which do not have any characteristics in common with surrounding deposits. The relationships which may exist between the oceanic series and those of the continental slopes and platform are obscure except on profile OC 102, where Formation 2 appears to insert itself in the platform series. However, the definition of the seismic data is too poor on the continental shelf for a precise correlation. Table 2 summarizes the quality of correlations between physiographic divisions and within each division, and the reasons for the estimates. The term "analogy" means that correlation is based only on seismic facies analogies.

Acoustic formations so defined and correlated may be related to the lithologic column of Site 398 as described below.

\section{Formation 4}

Strongly layered with velocities near $3 \mathrm{~km} / \mathrm{sec}$, Formation 4 corresponds narrowly with Units 5 and $4 \mathrm{C}$ (Hauterivian to Aptian), and consists of fine limestones and marls grading into turbiditic non-calcareous sandstones and siltstones. The strong reflector at the top of Formation 4 may be identified in the area of the DSDP site with the coarse turbiditic limestone bed at 1430 meters. Drilling stopped in Hauterivian dense limestones conformable with the basement layers at the drill site. Thus, all the Neocomian there may be identified as belonging to "acoustic basement."

\section{Formation 3}

Seismically transparent with velocities generally lower than $2.5 \mathrm{~km} / \mathrm{sec}$, this formation represents the Albian to Cenomanian "black shales" sequence, consisting of dark claystones and mudstones deposited beneath the carbonate compensation depth.

\section{Formation 2}

As the relative depth of the CCD lowers, the carbonate content of sediments increases, but not in a regular manner. There are fluctuations in the $\mathrm{CaCO}_{3}$ content and, correspondingly, in velocities and bulk density in lithologic Units $3 \mathrm{~B}, 3 \mathrm{~A}$, and $2(900$ to $500 \mathrm{~m}$, Campanian to Eocene). In this way, the units of varying $\mathrm{CaCO}_{3}$ content can be correlated with layered Formation 2 .

\section{Formation 1B}

Formation 1B, as defined in the abyssal plain, is not easily correlated with any formation at Site 398 . Because Formation 1B is well represented south of Site 398 , we can tentatively correlate it with the upper part of the layered sequence in profile GP 19, i.e., Unit 1C and the lower part of borehole Unit 1B (510 to $400 \mathrm{~m}$; Oligocene and early Miocene age).

\section{Formation 1A}

Most of Units 1B and 1A, consisting of unconsolidated sediments of uniform carbonate content, can be correlated with Formation 1A. This explains the isotropic character of the formation in the profiles ( 400 to zero $\mathrm{m}$, late Miocene to present).

If we try to extend the correlations towards the Bay of Biscay, it may be seen that Formations 1, 2, and 3 in the Iberian margin are roughly the same as Forma- 


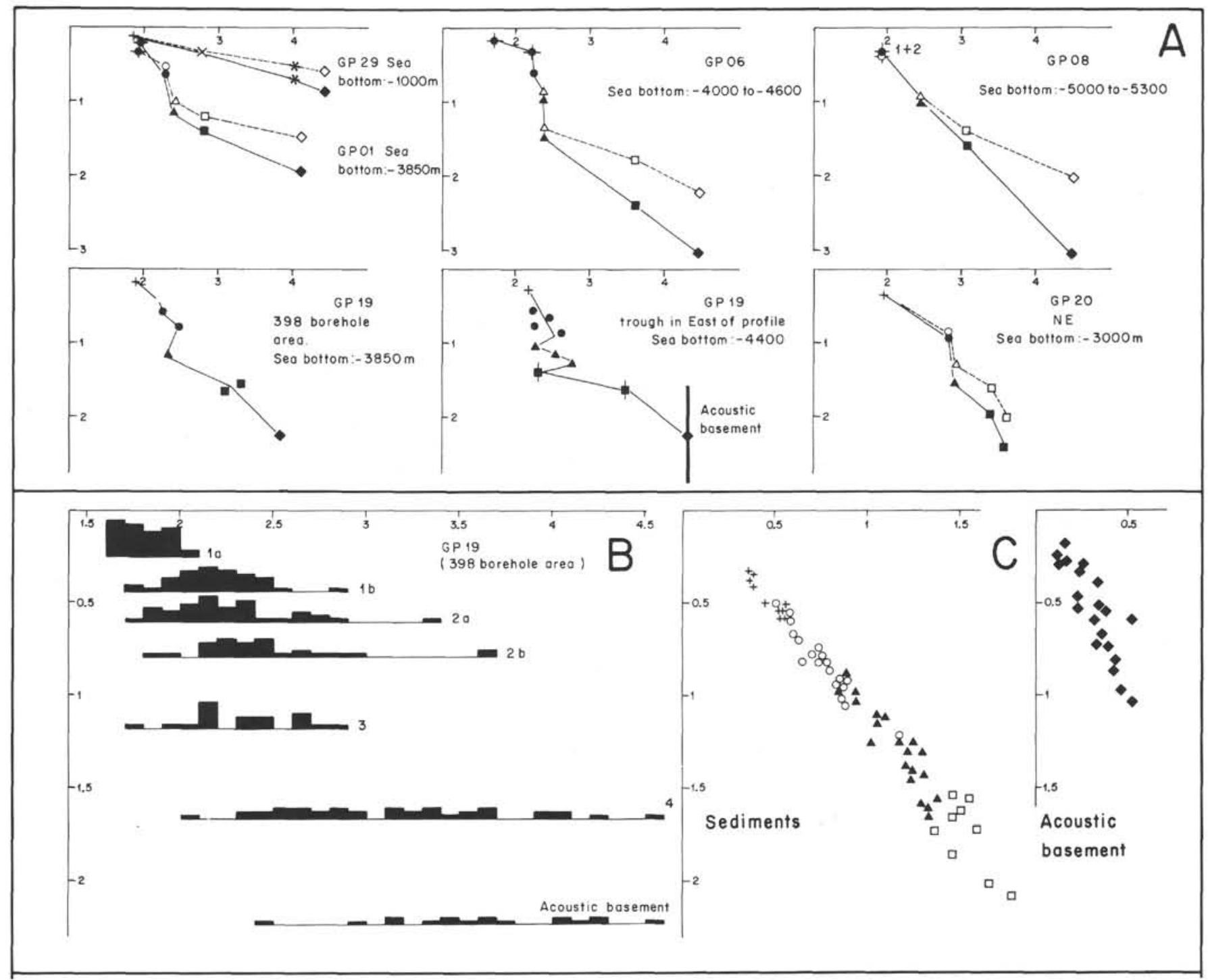

Figure 10. Relationship between interval velocity and depth below sea bottom. (A) Mean Formation velocity (horizontal scale) for different formation mean depths (vertical scale) in the Iberian Abyssal Plain (upper row) and the Vigo Seamount area (lower row). Empty figures and dashed lines = velocity versus two-way travel time. Black figures and solid lines $=$ velocity versus calculated depth in kilometers. Crosses $=$ Formation 1, circles $=$ Formation 2, triangles $=$ Formation 3, squares $=$ Formation 4, lozenges $=$ acoustic basement . Vertical scale $=$ seconds and kilometers below sea bottom. Horizontal scale $=$ kilometers per second. (B) Frequency distribution of velocities versus formation depth below sea bottom at Site 398 area. Horizontal scale $=$ velocity in $\mathrm{km} / \mathrm{sec}$, vertical scule $=$ depth in kilometers. $(C)$ Two-way travel time $($ horizontal scale in seconds) versus calculated depths (vertical scale in kilometers) in sediments and basement along part of profile GP 19 crossing a sedimentary trough. For the basement, the reference depth is below sediment-basement interface. $(D, E)$ Mean curves drawn from plots such as presented in C; curve obtained from core measurements at Site 398 is shown for comparison. The mean curves drawn on transparencies were used for the construction of depth sections from seismic profiles.

tions 1, 2, and 3 previously established in the Bay of Biscay. Hence, the ages attributed to Formations 1 and 2 (Recent to Oligocene-Eocene to Late Cretaceous, Montadert et al., 1974) after the data collected in JOIDES Drilling Sites 118 and 119 (Laughton, Berggren, et al., 1972), and the age postulated for Formation 3 (Early Cretaceous) are mostly confirmed by stratigraphic data from Site 398. Formation 4 of the western Iberian margin cannot be correlated with that already distinguished in the Bay of Biscay.

\section{STRUCTURE AND STRUCTURAL EVOLUTION}

The continental margin around Galicia Bank, and Vigo and Porto seamounts is severely faulted. Faults and flexures (represented by the same symbol in Figure 12) determine structural highs (usually horsts or 


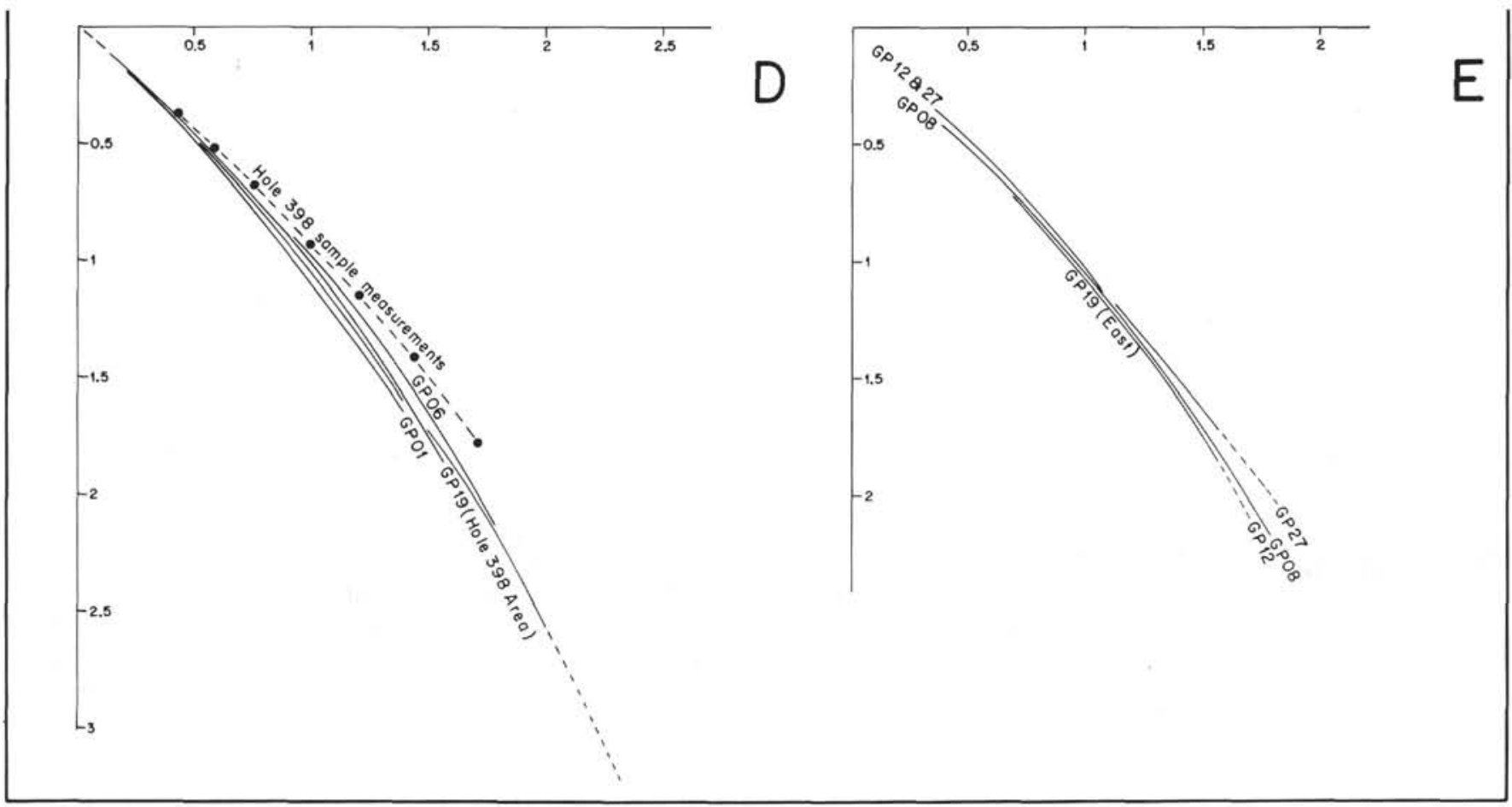

Figure 10. (Continued).

semi-horsts) where acoustic basement outcrops locally, and lows (grabens, semi-grabens, and wide basins) with a thick sedimentary cover.

Present-day morphology (Figure 2) faithfully reflects the structural framework. The banks are high zones and horsts, the depressions are grabens and basins, the steep slopes correspond to faults, Figures 2 and 12 can practically be superimposed.

Some structures are old and buried under sediments, or still form high zones (Mounts Vasco da Gama). Other relief was formed by faults also active during the Tertiary.

\section{Direction and Origin of Fractures}

The faults and flexures near Galicia Bank are roughly oriented in three prominent directions: NESW, NW-SE, and N-S. However, differences appear between the areas situated north and south of $42^{\circ} \mathrm{N}$. In the north (Galicia Bank), faults oriented $150^{\circ} \mathrm{E}$ and $40^{\circ} \mathrm{N}$ predominate (Figure 12A), whereas in the south (Vigo and Porto seamounts), the predominate direction is $60^{\circ} \mathrm{E}$ and north (Figure 12B).

Except for the fewer north-south faults, the basement of the Iberian Peninsula shows similar structural orientation. These are reflected in old faults of Stephanian and Permian age (Parga, 1969; Arthaud and Matte, 1975). These fractures, however, were active again in the Mesozoic and Cenozoic. This is especially true on the continental margin, whose sedimentary and structural evolution were thus controlled during periods of both Mesozoic distension and phases of Cenozoic compression (Boillot et al., 1974). It is possible that north-south direction, which is not obvious in the inland basement of the peninsula, is of a different origin and only appeared during the rifting phase.

\section{Structural and Sedimentary Evolution During the Mesozoic}

The west Iberian continental margin has been successively affected by two episodes of rifting related to two probable phases of the ocean in that part of the Atlantic. The geological history of the neighboring continent and of the Atlantic margin generally shows initial Triassic rifting. We discuss here the effects of the second (Late Jurassic-Early Cretaceous) rifting.

Formation 4 (Neocomian to Aptian) was deposited during active faulting. It appears, therefore, that active rifting took place at the same time that Formation 4 was deposited.

During the deposition of Formation 3, which corresponds to the Albian "black shales," the earlier tectonic rifts were gradually filled, whereas the normal faults that bound them remained active. It appears that the vertical movements were an isostatic response to the sedimentary overloading in the basins rather than to the effect of active rifting. Thus, it is probable that oceanic spreading began after deposition of Formation 4. Finally, during the late Cretaceous (Formation 2), local subsidence practically stopped, the depressions were almost completely filled by differential sedimentation, and deposition took place in many places on horizontal surfaces. At this time, relief was restricted to Vasco da Gama Seamount, and to some crests and ridges on buried, tilted, fault blocks. The existence of 


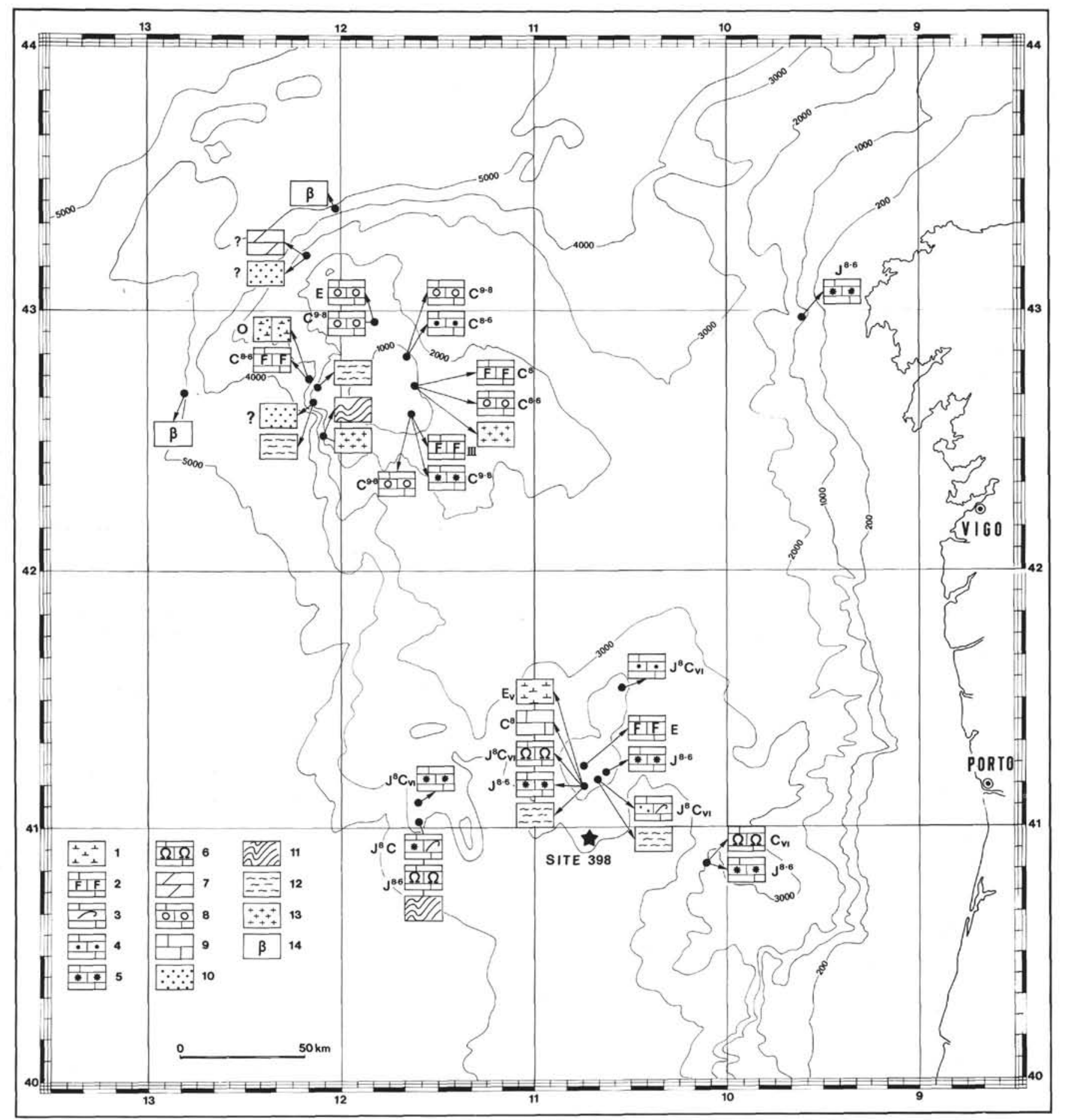

Figure 11. Summarized results of dredgings. $1=$ marl, $2=$ limestone and marl with foraminifers, $3=$ bioclastic limestone, 4 = detrital limestone, $5=$ limestone with algaes, $6=$ limestone with calpionellae, $7=$ dolomitic limestone, $8=$ chalk, $9=$ limestone, $10=$ sandstone, $11=$ schist and phyllite, $12=$ gneiss and granulite facies, $13=$ granite, $14=$ basalt . Stratigraphic series: $I I I=$ Tertiary undifferentiated (Neogene not symbolized), $O=$ Oligocene, $E=$ Eocene, Ev $=$ Paleocene, $C 9-8=$ Maestrichtian, C8 = Senonian, C8-6=Senonian and Turonian, J8-6 = Tithonian (Late Jurassic), CVI=Berriasian (Early Cretaceous), J8-C = Late Jurassic and undifferentiated Cretaceous. After Black et al. (1964, 4 dredges), Dupeuble et al. (1976, 9 dredges), and cruise Hespérides 76 ( 7 dredges, unpublished data). 
TABLE 2

Summary of Quality of Correlations Between Physiographic Divisions

\begin{tabular}{|c|c|c|c|c|c|c|}
\hline & Iberian Plain & Site 398 Area & Interior Basin & $\begin{array}{l}\text { Continental Slope } \\
\text { and Related Basins }\end{array}$ & $\begin{array}{l}\text { Continental } \\
\text { Shelf }\end{array}$ & Galicia Bank \\
\hline Iberian Plain & $\begin{array}{l}\text { Good, direct, gap } \\
\text { on } \mathrm{H} 9\end{array}$ & $\begin{array}{l}\text { Poor; structural } \\
\text { and erosional } \\
\text { features, only by } \\
\text { analogy }\end{array}$ & $\begin{array}{l}\text { Good by profile } \\
\text { T 9, partly } \\
\text { diachronous } \\
\text { (progradation) }\end{array}$ & & & $\begin{array}{l}\text { No correlation } \\
\text { except for recent } \\
\text { deposits, no } \\
\text { character analogy }\end{array}$ \\
\hline Site 398 Area & $\begin{array}{l}\text { Poor structural } \\
\text { and erosional } \\
\text { features, only } \\
\text { by analogy }\end{array}$ & $\begin{array}{l}\text { Good; direct and } \\
\text { by analogy }\end{array}$ & $\begin{array}{l}\text { Only by analogy, } \\
\text { poor by GP } 19 \\
\text { and } \mathrm{H} 32 \text {, struc- } \\
\text { tural and erosion } \\
\text { features }\end{array}$ & & & \\
\hline Interior Basin & $\begin{array}{l}\text { Good by profile } \\
\text { T 9, partly } \\
\text { diachronous } \\
\text { (progradation) }\end{array}$ & $\begin{array}{l}\text { Poor by GP } 19 \\
\text { and } \mathrm{H} 32 \text {, struc- } \\
\text { tural and ero- } \\
\text { sional features }\end{array}$ & $\begin{array}{l}\text { Good, direct, } \\
\text { some } \\
\text { progradation }\end{array}$ & $\begin{array}{l}\text { Generally bad } \\
\text { except for Form. } \\
1 \text {, and Form. } 2 \text {, } \\
\text { in OC } 102 \text {, } \\
\text { OC } 103\end{array}$ & & $\begin{array}{l}\text { No correlation, } \\
\text { except for recent } \\
\text { deposits - no } \\
\text { character analogy }\end{array}$ \\
\hline $\begin{array}{l}\text { Continental } \\
\text { Slope and } \\
\text { Related Basins }\end{array}$ & & & $\begin{array}{l}\text { Generally bad, } \\
\text { except for } \\
\text { Formation } 1 \text { and } \\
\text { Formation } 2 \\
\text { along OC } \\
102-103\end{array}$ & $\begin{array}{l}\text { Good, locally, } \\
\text { basins are } \\
\text { isolated }\end{array}$ & $\begin{array}{l}\text { Bad, gaps due to } \\
\text { scarps }\end{array}$ & \\
\hline $\begin{array}{l}\text { Continental } \\
\text { Shelf }\end{array}$ & & & & $\begin{array}{l}\text { Bad, gaps due to } \\
\text { scarps }\end{array}$ & & \\
\hline Galicia Bank & $\begin{array}{l}\text { No correlation } \\
\text { except for } \\
\text { recent deposits; } \\
\text { no character } \\
\text { analogy }\end{array}$ & & $\begin{array}{l}\text { No correlation } \\
\text { except for } \\
\text { recent deposits; } \\
\text { no character } \\
\text { analogy }\end{array}$ & & & $\begin{array}{l}\text { Good along OC } \\
106 \text { and GP } 29\end{array}$ \\
\hline
\end{tabular}

such important topographic features as Galicia Bank and Vigo Seamount during this epoch will be discussed later.

\section{Structural Evolution During the Cenozoic}

Age and Nature of Tertiary Tectonic Movements

The analysis of seismic recordings reveals two tectonic phases during the Cenozoic age.

1) The large fault along the northwest edge of Galicia Bank continues to the southwest as a flexure which affects Mesozoic and Eocene layers without disturbing more recent deposits. Tectonic movements occurred during the late Eocene (Figure 13). Movements of the same age are also seen in the Interior Basin.

2) Certain faults have moved recently, displacing an important part of the upper Tertiary series (Neogene phase, Figure 14).

Actually, the Iberian margin reflects the effects of numerous episodes of strain during the Cenozoic, as shown by studies on adjacent oceanic areas and on the neighboring continental plateau (Lamboy and Dupeuble, 1975; Lamboy, 1976; Boillot et al., 1975; Baldy et al., 1977; Boillot and Mougenot, 1977). It still remains difficult, however, to reconstitute them in detail and to state their precise nature. Some movements suggesting Eocene compression and reverse faults have been observed in the abyssal plain, northwest of Galicia Bank (Figures 15 and 16). Other movements may have caused normal faults. Additionally, the northeast-southwest faults west of Galicia Bank with a reverse component also may have acted as wrench faults.

\section{Structural Evolution of the Vigo Seamount Area}

Vigo Seamount, with its central infilled basin and its almost flat rim, is most interesting. It may be regarded either as an uplifted block or as an incompletely subsided part of the continental margin.

The first interpretation (Boillot, Mauffret, Auxiètre) is based on the fact that, whereas almost every high on the margin is only covered with thin sediments, the pre-Oligocene sedimentary series on Vigo Seamount is almost as thick on top as it is at the foot of this feature. This series only shows minor differences as regards its thickness and seismic character. We interpret this apparent identity between layers which are now at more than 1500 meters difference in elevation as reflecting continuity of bedding during the Mesozoic. Vigo Seamount then formed in the Tertiary as the result of tectonic movement. Figure $17 \mathrm{~A}$ shows this interpretation and also describes the previous stages of structural evolution. Those stages begin with Upper Jurassic-Lower Cretaceous distension and deposition of Formation 4; then intervenes a local subsidence in the tectonic riftvalleys (Formation 3 or "black shales"), and lastly general leveling of the Upper Cretaceous topographic surface (sedimentation of Formation 2). However, this monotonous relief was completely disrupted during the Tertiary by the formation of new relief, including Vigo and Porto seamounts. The sedimentary series infilling Vigo 


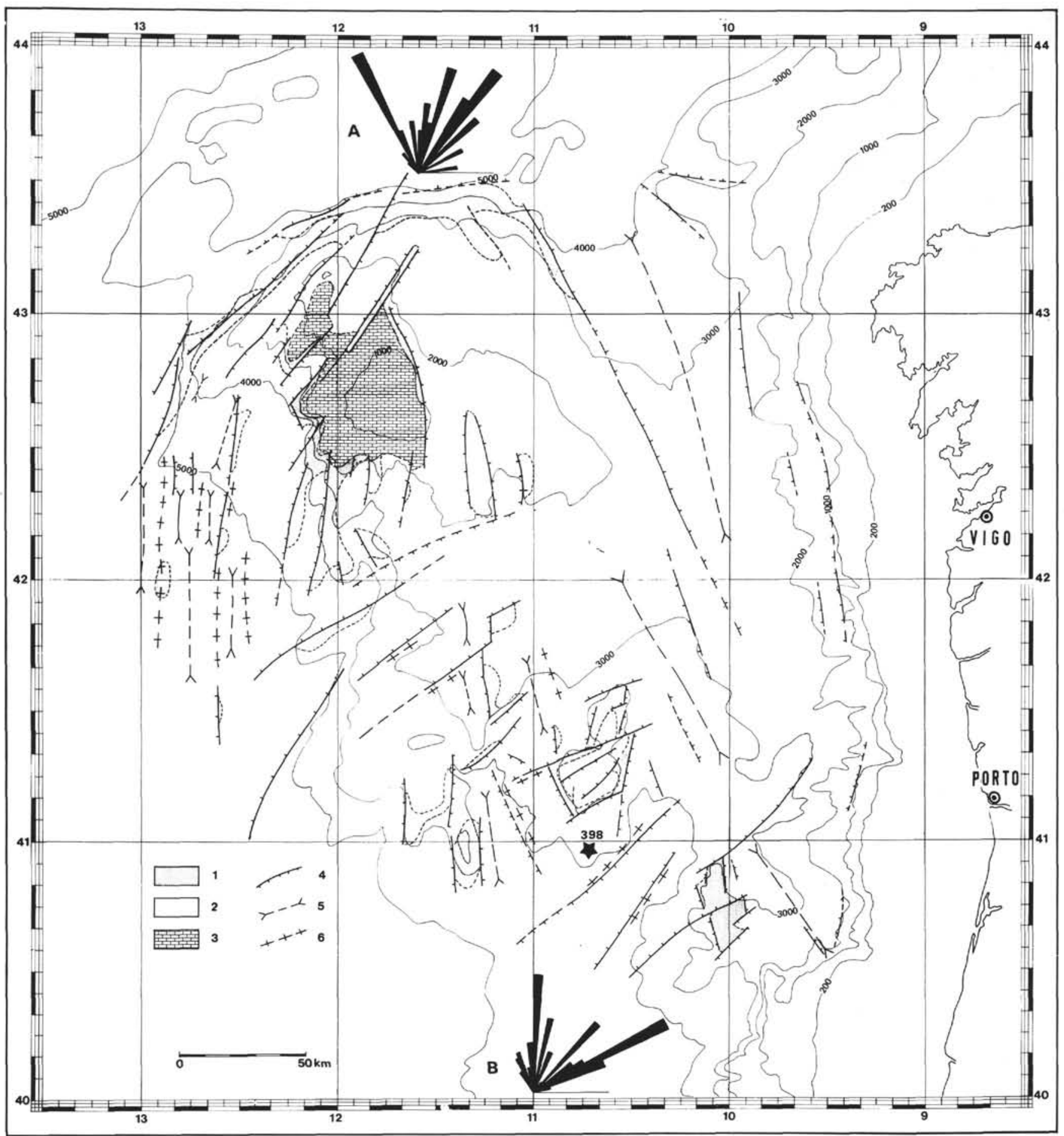

Figure 12. Structural map. 1 = Acoustic basement outcrop, $2=$ Cenozoic cover, $3=$ Cretaceous and Cenozoic cover $/$ Galicia Bank), $4=$ Fault, $5=$ Basin axis, $6=$ Ridge axis. $A$ and $B=$ Frequency distribution of fault directions north of $42^{\circ} \mathrm{N}$ (A) and south of $42^{\circ} \mathrm{N}(\mathrm{B})$.

Seamount's central basin and those at its toe remain identical up to the Tertiary, then differ completely since this period.

This interpretation, if accepted, has important consequences:

1) The Late Jurassic-Early Cretaceous series which could not be reached by Site 398 drilling is probably the same as that which outcrops on the sides of Vigo Seamount and was sampled during the Lusitania 74 and Hespérides 76 cruises.

2) The region northwest of the Iberian Peninsula cannot be considered as a typical passive continental margin since its normal evolution was interrupted by important tectonic movements in the Tertiary. 

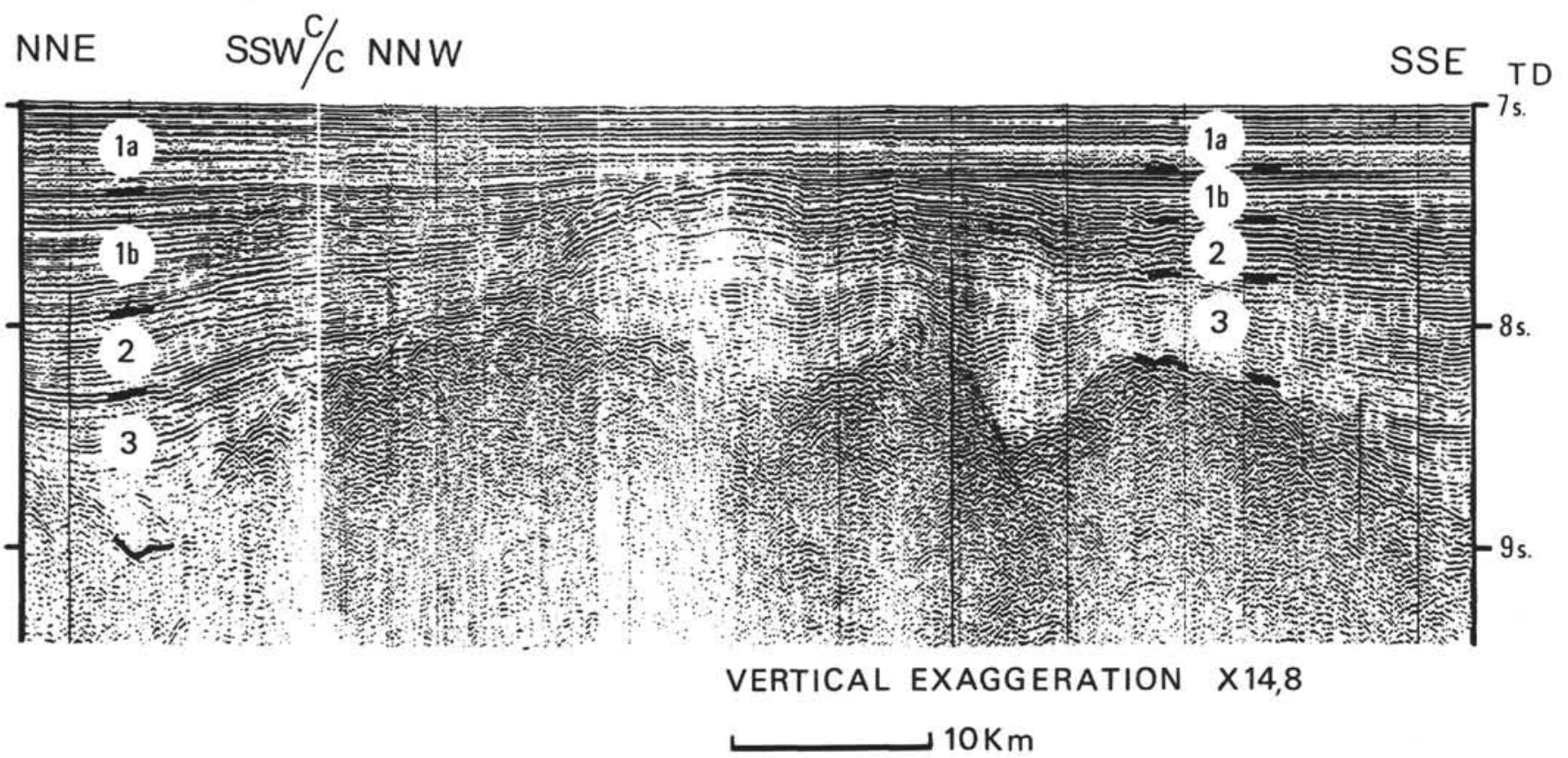

Figure 13. Section showing post-Formation 2 movements. In this figure, Formation 2 (Campanian to Eocene) is deformed, whereas Formation $1 b$ appears to overlap 2 and infill hollows.

NNW

SSE

TD

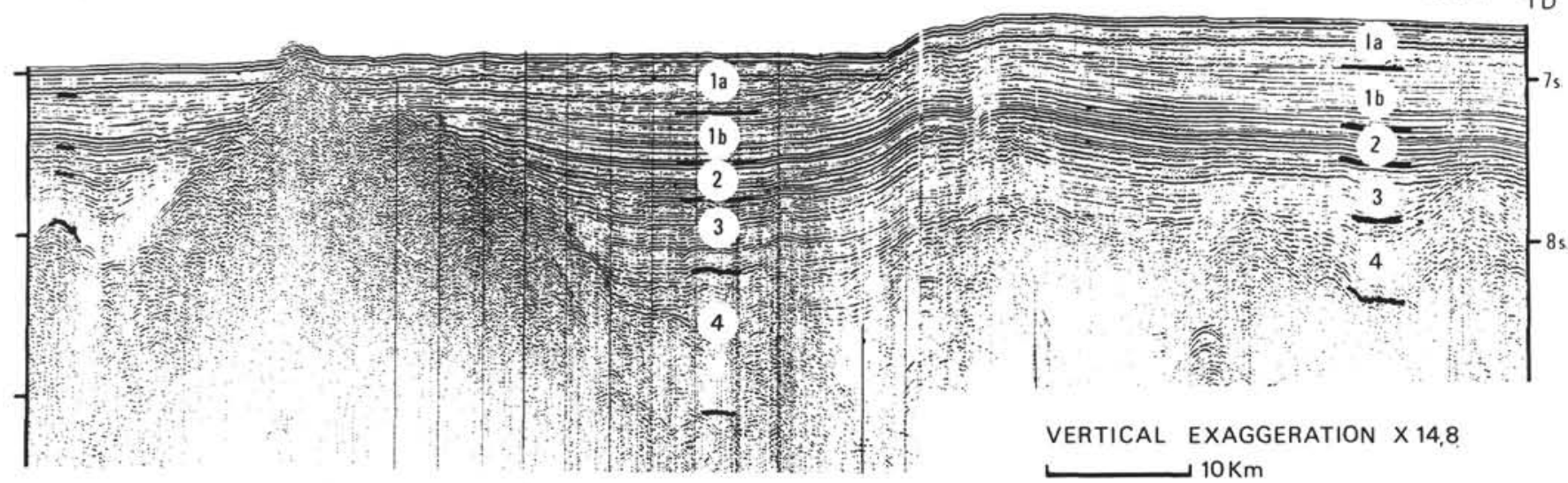

Figure 14. Neogene tectonic movement. On left, a tilted block basement remained as a passive relief feature during most of the sedimentation; on the right, a flexure caused gentle bending of sediment up to the formation 1 a/1b boundary (middle Miocene). Vertical scale $=$ two-way travel time in seconds.

The second interpretation of this area's structural evolution (Montadert, Sibuet, Da Charpal, Figure 17B), i.e., an incompletely subsided part of the continental margin, is supported by the existence of several erosional surfaces analogous to that on the flat rim of Vigo Seamounts's basement, which lie between Galicia Bank and Vigo Seamount. These surfaces truncate acoustic basement at roughly the same depth, $3.2 \pm 0.1$ seconds of two-way travel time. They are perfectly flat and could be remnants of the initial continental surface subjected to subaerial erosion while the other parts of the continent were foundering and submerged below sea level. As they subsequently remained at similar depths, they must only have undergone regional subsidence since that time, until they reached their present depth of 2500 meters.So, it seems that blocks bearing such erosional surfaces, in particular Vigo Seamount, were not uplifted during Cenozoic compression, otherwise they probably would not have remained at the same elevation. Using the same reasoning they could not have undergone important distensional movements during the Cenozoic. It is probable that Vigo Seamount remained as an important relief feature since the Early Cretaceous, i.e., since the rifting of the margin. It may have contributed to the coarse limestone clasts found in the turbiditic material at Site 398 at the foot of Vigo Seamount. 


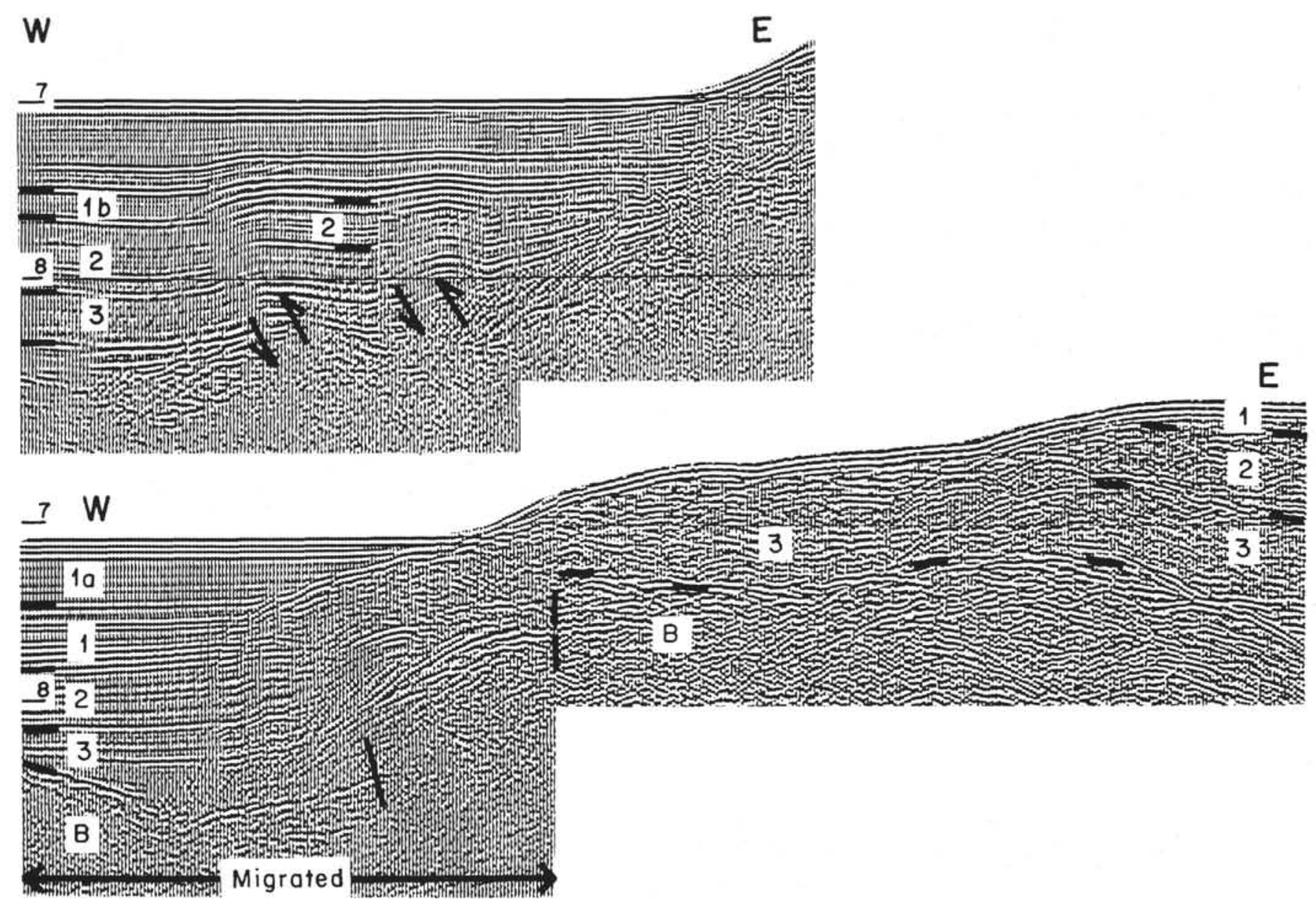

Figure 15. Paleogene reverse fault and other vertical movements. Upper profile (GP 01, migrated). The fault on the left is characteristically reverse. It affects Formation 3 isopachs, whereas part of the upper Formation 2 appears to be condensed in the uplifted block, so that deformation appears to be contemporaneous with it and, therefore, is probably of Eocene age. Formation $1 b$ is only slightly deformed or overlapping. Lower profile (GP 04). Although more obscure than in the upper profile, reverse faults or faults with a reverse component may also be present in this section, with important vertical displacement; probable age is Eocene to Oligocene. Vertical scale = two-way travel time in seconds.

\section{Structural Evolution of Galicia Bank}

The sedimentary cover of the Galicia Bank contains some neritic Upper Cretaceous (Maestrichtian: Black et al., 1964), which shows that the bank was already in existence at this time. If our first interpretation of Vigo Seamount also applies to Galicia Bank, we would have to accept that the tectonic movements which elevated the Iberian marginal banks were pre-Maestrichtian, which is possible but has not been proved. Two interpretations for the evolution Galicia Bank therefore remain, as is true for Vigo Seamount.

a) The Bank is a horst which formed in the Early Cretaceous during rifting. It has been a slightly subsiding feature since then and is covered by carbonate shelf deposits of Senonian age (Montadert et al., 1974)

b) The Bank is a Senonian horst due to a compressive episode whose effects are known in the Pyrenees and on the Iberian northern margin (Boillot et al., 1971a, b, 1973; Lamboy and Dupeuble, 1975; Choukroune, 1976; Boillot and Capdevila, 1977).
In the first case, Galicia Bank and Vigo Seamount underwent differential subsidence and the structural contrast observed north and south of the $42^{\circ} \mathrm{N}$ (Figure 12 ) is an effect of this difference. In the second case, the uplift of marginal banks (horsts) probably resulted from the subduction of the ocean bed of the Bay of Biscay under the Iberian Penisula, which took place in the Late Cretaceous and early Eocene (Montadert et al., 1970, 1971; Montadert and Winnock, 1971; Sibuet and Le Pichon, 1971).

In either event, it is clear that important tectonic movements took place in the Tertiary, particularly in the Eocene. Even if Galicia Bank is a Mesozoic horst, the faults which border it moved again in the Cenozoic, and the present morphology is partly a result of Tertiary movements.

\section{CONCLUSION}

In the proposed reconstruction of continents, during Trias and Lias (Figure 18), Galicia Bank area is lo- 


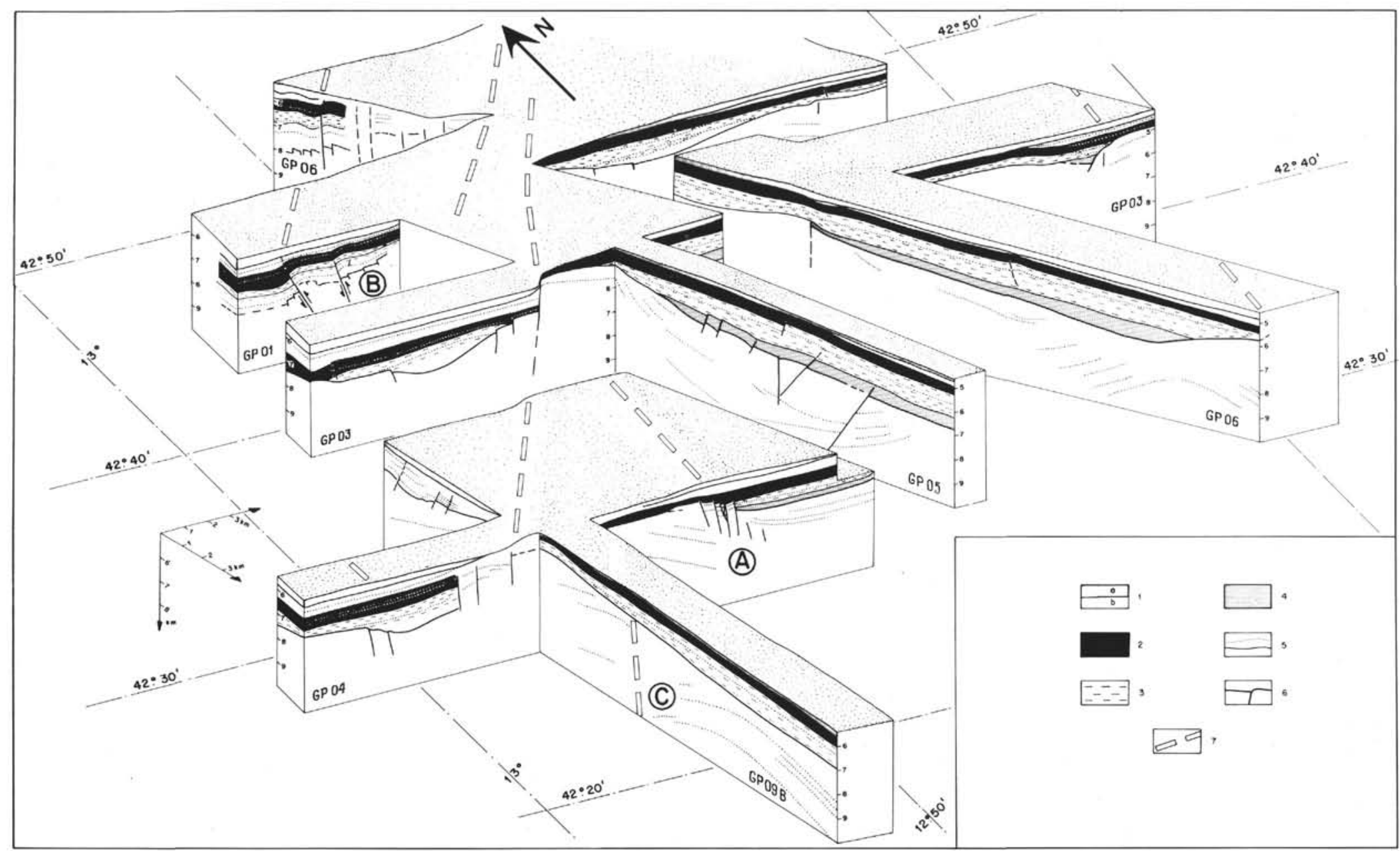

Figure 16. Structure of Galician-Portuguese margin west of Galicia Bank. Sections are viewed from the southwest. Sediments are shown with their deformations. Synrift deformation (prior to Formation 3) is normal block faulting, as in A. Post-rift deformation (during and after deposition of Formation 2) is conspicuous as vertical and inclined faults with a reverse component (see B). It is also possible that movement during this epoch (Eocene) took place along former normal faults. Dips in the acoustic basement suggest that rocks were gently folded, then eroded, before rifting (see C). Vertical scale $=$ kilometers below sea level; no vertical exaggeration. $1,2,3,4=$ Formation numbers. $5=$ Seismic reflectors $($ solid lines $=$ boundaries between formations, dotted lines $=$ other sedimentaries reflectors). $6=$ heavy solid lines indicating top of acoustic basement and faults. $7=$ Projection of the major faults on the sea bottom. 

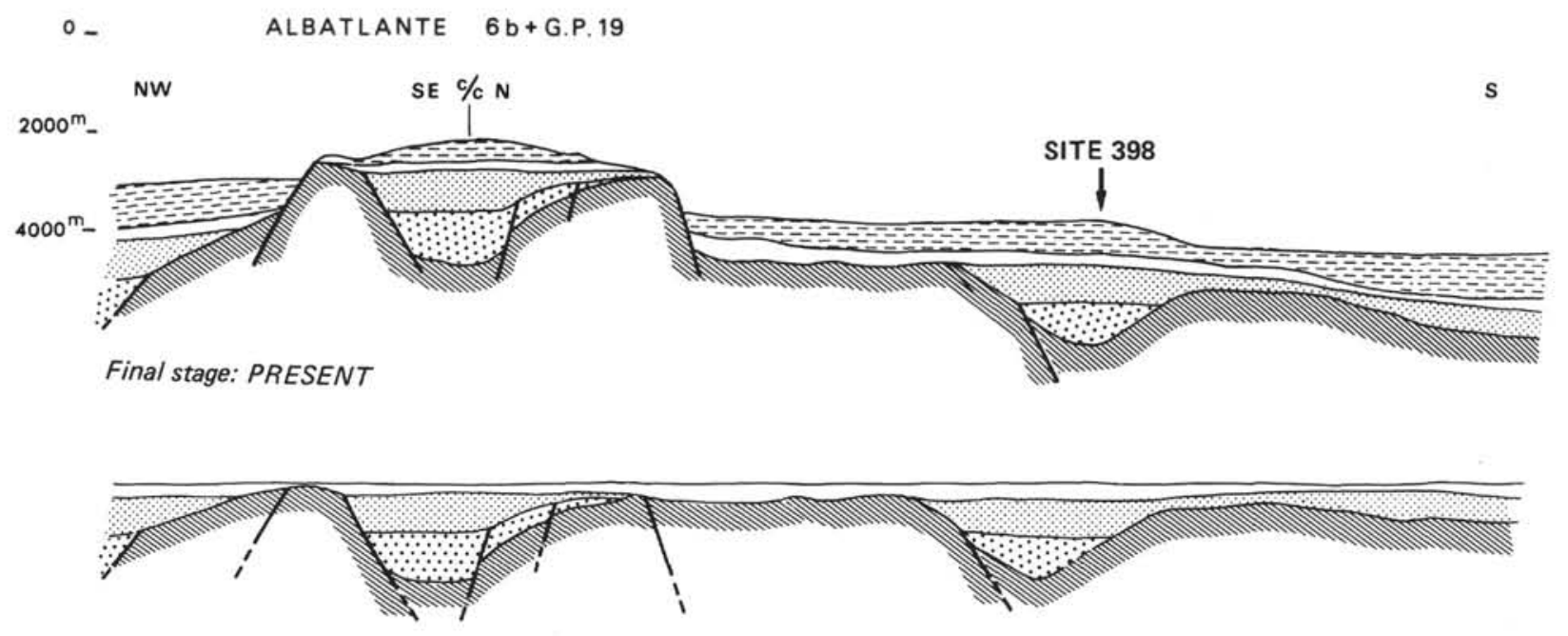

Middle stage: EOCENE

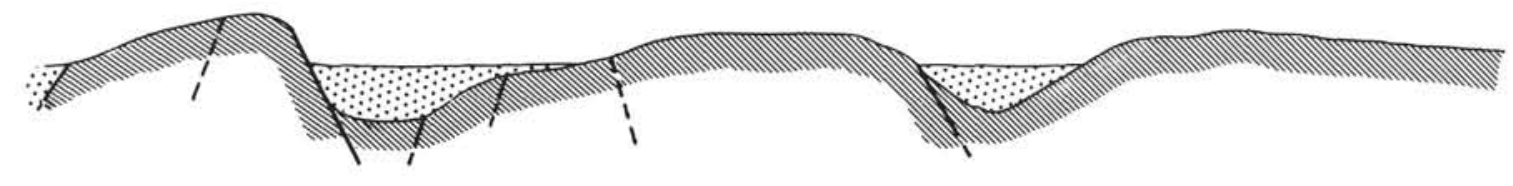

Early stage: EARLY CRETACEOUS

(a)
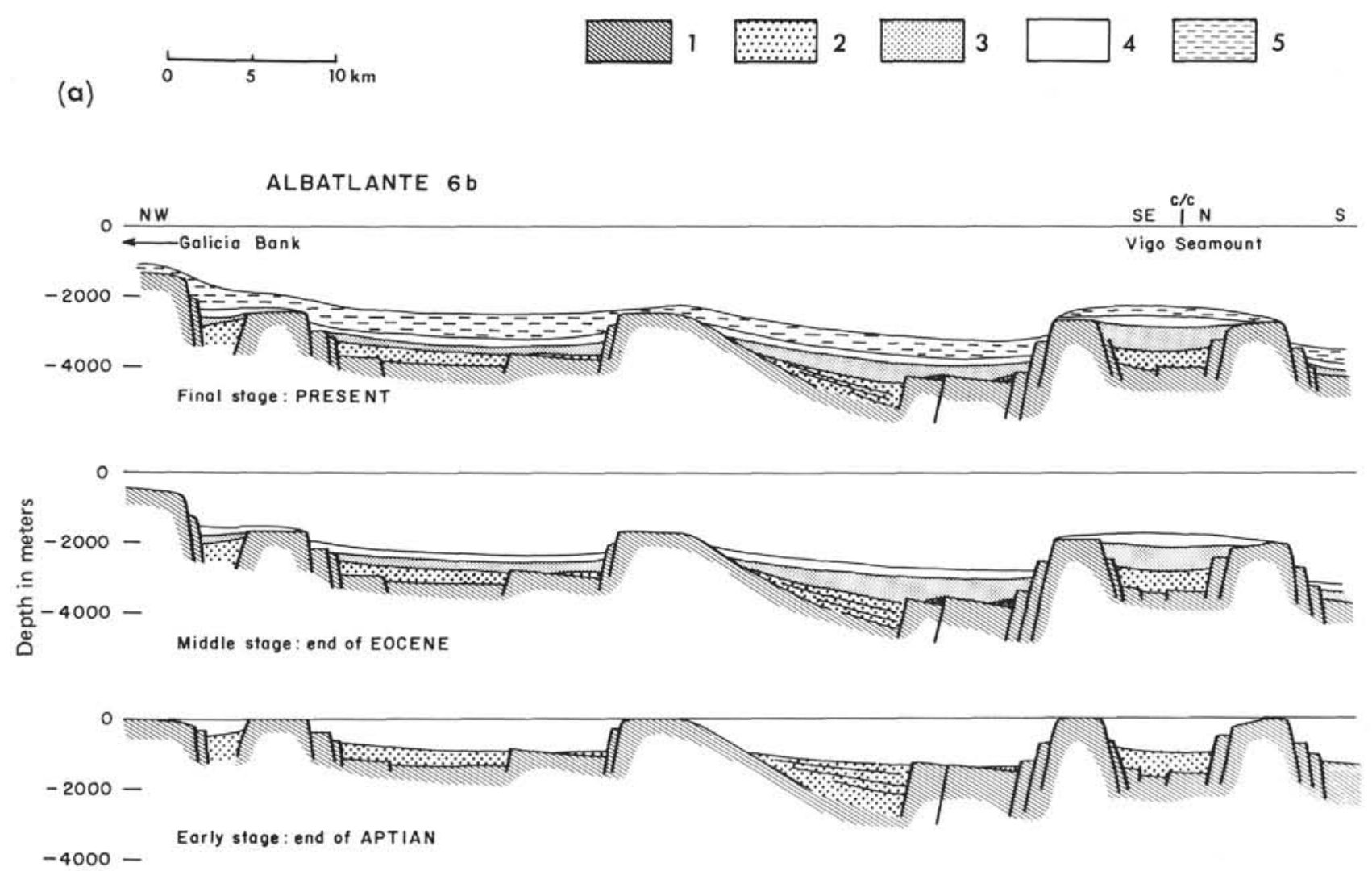

(b)

Figure 17. Tentative reconstructions of Vigo Seamount's structural history: (a) as a block raised during Cenozoic times; (b) as a block synchronous with the rifting. 1 =acoustic basement, $2=$ infilling series (Formation 4$)$, $3=$ Formation 3, 4 = Formation 2, 5= upper series (Formation 1). 


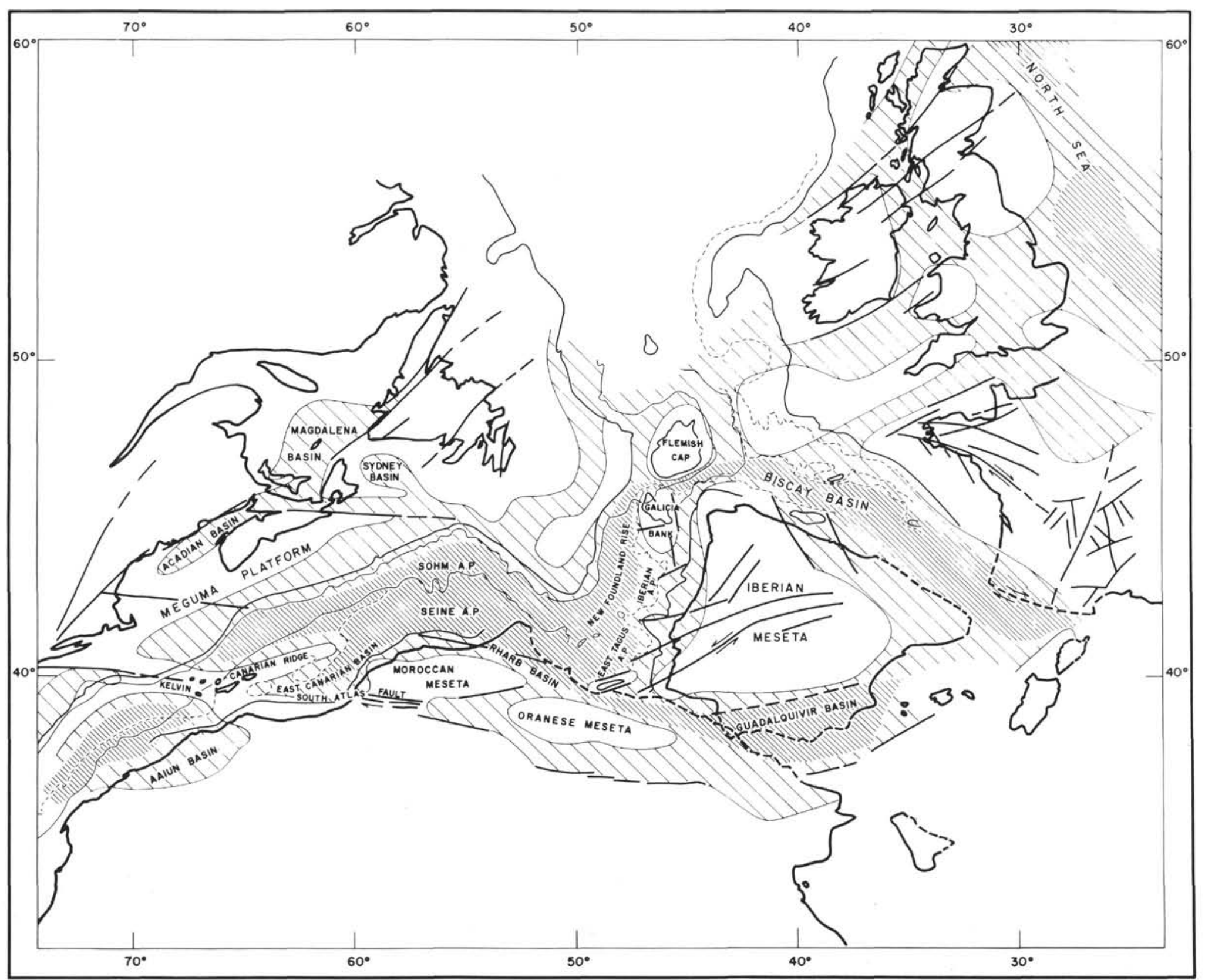

Figure 18. Position of continents during Trias-Liassic. North America is fixed. The rotation parameters are: Europe/N. America: $89^{\circ} 1 \mathrm{~N}, 103^{\circ} 1 \mathrm{~W}, 29^{\circ} \%$; Iberia/N. America: $73^{\circ} 9 \mathrm{~N}$, basins from carboniferous until Liassic, Limits of oceanic basins inferred from evaporitic deposits (after Olivet et al., in preparation; from data of Pautot et al., $1970 ;$ Sibuet et al, 1971 . Bonnin et al., 1973; Grunau et al., 1975; Schlee et al., 1976, Olivet et al., 1976). 
cated between the three major plates of Africa, North America, and Europe (see also Laughton, Berggren, et al., 1972; Le Pichon et al., 1977). This area is within a complex region north of the Kelvin Seamount-South Atlasic line and was affected by several tensional stress phases between the late Carboniferous (Pennsylvanian, 300 m.y.B.P.) and the late Lias (180 m.y.B.P.). The relative significance of these tensional phases is still under discussion (Ziegler, 1975; Arthaud and Matte, 1975), but we may assume that the origin of the continental margin around Galicia Bank dates back to Trias or earlier.

However, the first period of Iberian margin history about which we possess some reliable data is Triassic and/or Early Jurassic. Series of this age occur onland on the periphery of Iberia and the Portuguese continental shelf. The deposits are partly clastic, partly evaporitic and dolomitic. Sedimentary sequences with evaporites are also recorded in the small basins of the continental slope and probably in some parts of the Interior Basin. West of Galicia Bank and in the Iberian Abyssal Plain, troughs infilled by a thick sedimentary sequence may contain pre-Neocomian or older sediments. This is likely since they are located in a zone east of the probable eastern limit of the late Aptian Cretaceous magnetic quiet zone. This signifies that deposition of lower Mesozoic layers could have taken place in grabens formed well before the Lower Cretaceous. Whether they are evaporitic or not is questionable since there are no convincing diapiric structures. In any case, grabens of this age are known in Portugal, and distensive tectonism with Triassic infill occurs on the North American margin (Pautot et al., 1970; Amoco, 1973; Schlee et al., 1976; Van Houten, 1977). Deposits of the same age should also occur, according to some interpretations, in the northern and southern Bay of Biscay (where they would prolong the evaporitic inland basin), and on the Tagus and Seine abyssal plains between Tore-Madeira Rise and the nearby evaporitic basins (Figure 18).

On the Iberian margin, fractures oriented in the same direction as the late Hercynian on-land faults seem to have controlled pre-Cretaceous basins.

The oldest dated samples are Jurassic. An abundance of large samples reveals a platform or reefal environment with open-sea influences in the Late Jurassic and perhaps the beginning of Cretaceous. To date, no rock of Early or Middle Jurassic age has been dredged.

The second great tectonic event is the Late JurassicEarly Cretaceous rifting. Aptian to Hauterivian, and perhaps Valanginian sedimentary infills are obviously contemporaneous with at least the final movements of horst and graben structures. However, the initial stage of distension cannot be easily dated because the great amplitude of fault movements and rapid subsidence obscure the sediment-tectonics relationship in the seismic imagery. The Site 398 data show that the site was already under deep water in Barremian-Aptian time, but we lack the crucial information which could have been provided by a borehole drilled on an elevated part of the region and another one down to Jurassic in a deep part. This information would have indicated if a differentiation already existed in the Late Jurassic (dredges brought up only samples from seamounts) and what sort of difference may exist between sedimentation on highs and lows during the Hauterivian or Barremian.

During this important stage of rifting, a strong relief was created on the continental slope and by the seamounts. North/south faults functioned parallel to the continental margin. Their movement may have resulted in breaks in margin sedimentation or erosion, as appears in particular on the seismic profiles of the northwest and northeast Atlantic (Sherwin, 1973; Amoco, 1973; Winnock and Fried, 1973; Wilson, 1975).

After the rifting phase, it seems that the entire margin subsided and that differential movements ceased, at least those resulting from distension. Some movement might have continued as an isostatic response to the sedimentary overburden. Thick and rapid sedimentation of the Albian "black shales" took place during this period and infilled the troughs. According to the magnetic data, a rapid expansion of the oceanic floor created the Iberian Abyssal Plain (Cretaceous magnetic quiet zone).

The effects of erosional processes and a slight unconformity at the end of the Albian are visible everywhere. The character of sedimentation changed and pelagic carbonates replaced clayey mudstones. In many places, sedimentation took place on "leveled surfaces," although seamounts were still present. Seismic evidence shows that bottom currents began to prevail which were strong enough to cause incline bedding. From Cenomanian to Campanian time, sedimentation was condensed and ocean current action increased and persisted throughout the Cenozoic up to the present at the foot of the continental slope. This indicates important changes in the environment. On land, it is well known that the Cenomanian is a time of general transgression, with corresponding changes in the microfaunal distribution in Europe and America (Jansa and Wade, 1975). In the North Atlantic, there are breaks in deposition, changes to carbonate sediments, and a greater abundance of planktonic fauna. Drilling of the subsided Orphan Knoll, shows lack of deposition during most of the Late Cretaceous, with pelagic sedimentation following (Site 111 of JOIDES Leg 12, Laughton, Berggren, et al., 1972). All these events may be related to an increased rate of sea floor spreading in the early Cenomanian (Larson and Pitman, 1972; Hays and Pitman, 1973), and to the opening of the North Atlantic between Labrador and Europe.

Galicia Bank area is enclosed between two major tectonized belts which are the western prolongation of the Pyrenean orogen and of the Betic and Rif system (Figure 19).

The northern belt was affected by the Late Cretaceous-Eocene tectonic phase and by minor OligoceneMiocene movements. Relative vertical movements and flexures resulted in a rejuvenation of the bottom topog- 
raphy; we have already stated that faults with reverse component occur to the west of Galicia Bank. This shows that the margin underwent compressional stresses, which can be related to compressive events of the Pyrenean phase sensu lato. Manifestations of the Pyrenean phase are obvious in the Bay of Biscay (Figure 19) as an angular unconformity in the sedimentary sequence (Laughton, Berggren, et al., 1972) and by the occurrence of subduction north of the Iberian Peninsula (Le Pichon and Sibuet, 1971a, b; Montadert et al., 1970, 1971; Montadert and Winnock, 1971; Boillot and Capdevila, 1977).

The southern belt, which includes the Tore-Madeira Rise and the Gorringe Bank area, has been affected mostly by a Miocene compressive episode. These Miocene movements, marked by a hiatus between seismic layers 1A and 1B, are as well displayed south of Galicia Bank as they are in the Tagus, Horseshoe, and Seine abyssal plains (Figure 19), where intense deformation has affected the continental margin, the ToreMadeira Rise, and the Gorringe and Ampere banks (Olivet et al., 1976b). They are probably linked to the alpine tectonics of early to middle Miocene age which affects the Betics and northern Africa.

Consequently, Galicia Bank occupies a zone of critical interest with respect to the principal east-westtrending belts of deformation that lie to the north and south. The interpretation illustrated in Figure 19 is that Galicia Bank is relatively undeformed, having remained welded to the rigid blocks that border it, namely, the Iberian land mass to the east and the Iberian deep-sea basin to the west. However, the possibility is not excluded that Galicia Bank, which is a narrow, continental margin structure, responded to the inferred WNW, ESE stress and is therefore the site of intra-plate deformation.

\section{ACKNOWLEDGMENTS}

The authors express their gratitude to G. A. Auffret and L. Pastouret, contribution No. 533 of the Scientific Department of the Centre Océanologique de Bretagne, J. P. Réhault and J. R. Vanney (University of Paris), B. de Givry and Y. Godart (Institut Français du Pétrole), who took an active part in this work. They are especially indebted to the crews and scientific teams of the O.S. J. Charcot, Le Noroit (Centre National pour l'Exploitation des Océans), and Florence (Institut Français du Pétrole, Laboratoire du Verdon), who participated in the geophysical cruises and the dredgings, and to the geophysicists of Société Nationale des Pétroles d'Aquitaine (now SNEA P) and of Bureau d'Etudes Industrielles et de Coopération de l'Institut du Pétrole, who processed the seismic data.

They are grateful to Dr. J. I. Ewing, both for having reviewed the text and for his useful advice relative to translation problems.

\section{REFERENCES}

Amoco, 1973. Regional geology of the Grand Banks; offshore exploration staffs, Canadian Soc. Petrol. Geol. Bull. Con Petrol. Geol., v. 21, p. 479-503.

Arthaud, F. and Matte, P., 1975. Late Hercynian wrench faults in southern Europe and northern Africa: geometry and nature of deformation, Tectonophysics, v. 25, p. 139-171.
Auffret, G. A., Pastouret, L., Auzende, J. M., and Olivet, J. L., 1976. L'évolution du Golfe de Gascogne et de ses marges, Fourth réunion Sci. Terre, Paris, p. 25.

Baldy, P., 1977. Géologie du plateau continental portugais au sud du cap de Sines, Thèse $3^{\text {eu }}$ cycle, Université de Paris VI.

Baldy, P., Boillot, G., Dupeuble, P. A., Malod, J., Moïta, I., and Mougenot, D., in press. Carte géologique du plateau continental sud-portugais et sud-espagnol (golfe de Cadix), Soc. Géol. Fr. Bull.

Berthois, L., 1966. Bathymetric maps of the continental slope and shelf, 11 sheet edited by Berthois and printed by the Centre Nat. Rech. Scientif. Paris.

Berthois, L. and Brenot, R., 1964. Bathymétrie du Golfe de Gascogne et de la côte du Portugal. I - Commentaires sur la levé complémentaire des feuilles 9 et 10 des abords du plateau continental. II - Bathymétrie du talus du plateau continental à l'ouest de la péninsule Ibérique du Cap Finisterre au cap Saint Vincent, cons. Intern. Expl. Mer, procèsverb., 52nd Réunion, Sept.-Oct. 1964.

Berthou, P. Y., 1973. Le Cénomanien de l'Estramadoure portugaise, Serv. Geol. Portugal, Mem., 23.

Berthou, P. Y. and Lauverjat, J., 1974. La limite Cénomanien-Turonien. Essai de corrélation entre la série portugaise à Vascoceras et les sèries de l'Europe de Sue-Ouest et de l'Afrique du Nord, C.R. Acad. Sci. Fr., v. 278, p. 2605-2608.

Black, M., Hill, M. N., Laughton, A. S., and Matthews, D. H., 1964. Three non magnetic seamounts off the Iberian coast, Geol. Soc. London Quart. J., v. 120, p. 477-517.

Boillot, G. and Capdevila, R., in press. The Pyrenees: subduction and collision, Earth Planet. Sci. Lett.

Boillot, G. and Mougenot, D., in press. Carte géologique du plateau continental portugais à $1 / 1000.000^{\mathrm{e}}$ et sa notice explicative, Serviços geológicos do Portugal.

Boillot, G., Depeuble, P. A., d'Ozouville, L., and Sibuet, J. C., 1971a. Structure et histoire géologique de la marge continentale du Nord de l'Espagne (entre $£^{\circ}$ et $9^{\circ} \mathrm{W}$ ). In Histoire structurale du Golfe de Gascogne: Paris (Technip), v. 2, p. V-6.1-52.

Boillot, G., Dupeuble, P. A., Durand-Delga, M., and d'Ozouville, L., 1971b. Age minimal de l'Atlantique Nord d'après la découverte de calcaire tithonique à Calpionelles dans le Golfe de Gascogne, C. R. Acad. Sci. Paris, v. 67, p. 671-674.

Boillot, G., Dupeuble, P. A., Hennequin-Marchand, I., Lamboy, M., and Leprêtre, J. P., 1973. Carte géologique du plateau continental nord-espagnol entre le Canyon de Cap breton et le Canyon d'Aviles, Soc. Géol. Fr. Bull., v. 15, p. 367-391.

Boillot, G., Dupeuble, P. A., Hennequin-Marchand, I., Lamboy, M., Leprêtre, J. P., and Musellec, P., 1974a. Le rôle des décrochements tardi-hercyniens dans l'évolution structurale de la marge continentale et dans la localisation des grands canyons sous-marins à l'Ouest et au Nord de la Péninsule Ibérique, Rev. Géogr. Phys. Géol. Dyn, Fr., v. XVI, n०1, p. 75-85.

Boillot, G., Lefort, J. P., and Rioult, M., 1974b. Carte géologique de la Manche, Bur. Rech. Geol. et Minières.

Boillot, G., Dupeuble, P. A., and Musellec, P., 1975. Carte géologique du plateau continental nord-portugais au nord du cap Carvoeiro, Soc. Géol. Fr. Bull., v. 4, p. 462-480.

Bonnin, J., Auzende, J. M., and Olivet, J. L., 1973. L'extrémité orientale de la zone Açores-Gibraltar: structure et évolution, Réunion Ann. Sci. Terre, Paris, p. 91.

Choukroune, P., 1976. Structure et évolution tectonique de la zone nord-pyrénéenne. Analyse de la déformation dans 


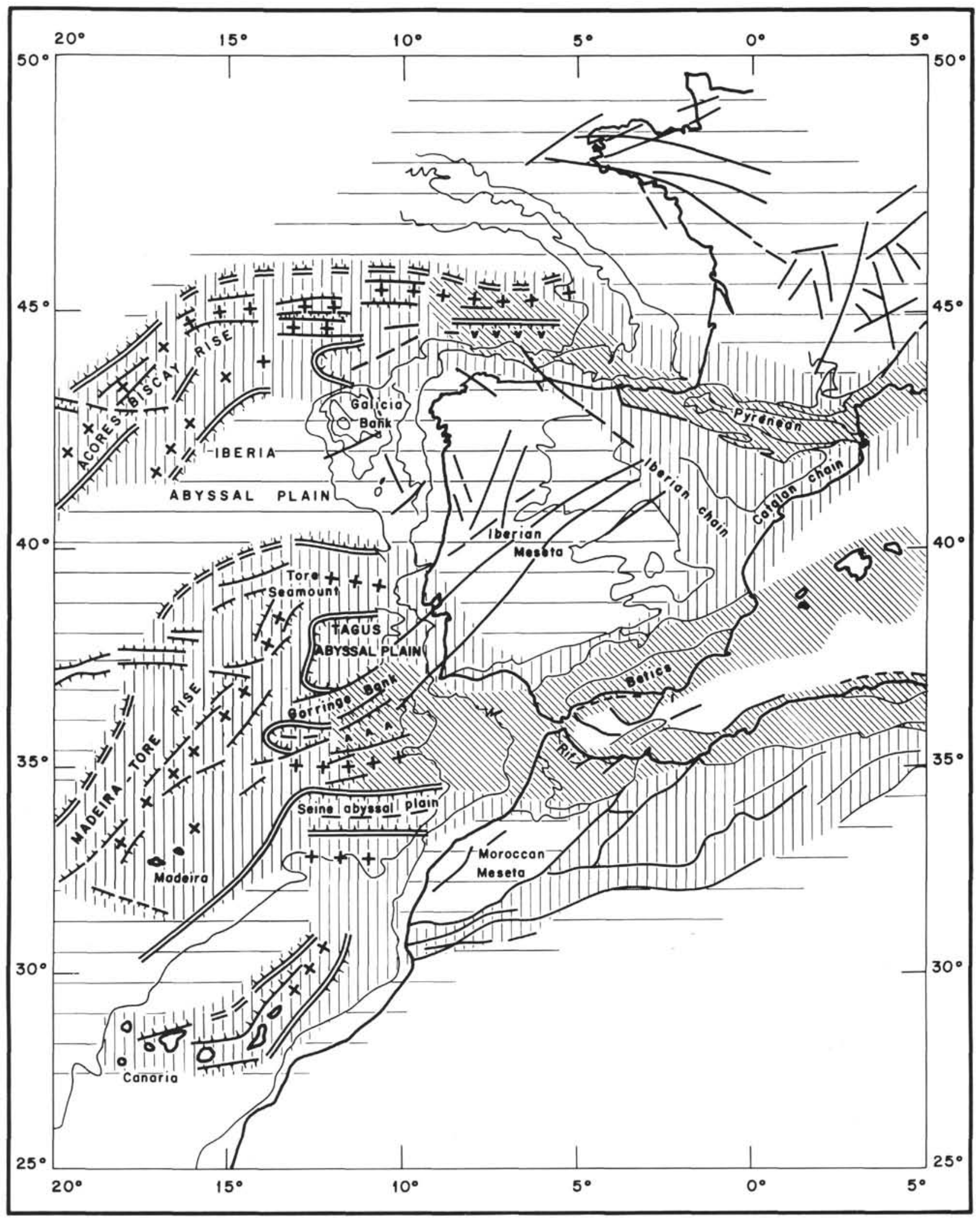

Figure 19. Upper Cretaceous and Tertiary tectonic elements near the Iberian Peninsula. $V=$ trenches with subduction, $+=$ axis of uplift area, $-=$ trench axis, double line $=$ boundary of uplifted area, solid lines $=$ main fracture zones (from bottom morphology in underwater areas), striped areas = zones deformed under compressive stress, vertical stripes $=$ weak deformation, oblique stripes $=$ intense deformation . 
une portion de chaîne à schistosité subverticale, Mém. Soc. Géol. Fr., 127.

Choukroune, P., Le Pichon, X., Séguret, M., and Sibuet, J. C., 1973. Bay of Biscay and Pyrénées, Earth Planet. Sci. Lett., v. 18, p. 109-118.

Dupeuble, P. A., Réhault, J. P., Auxiètre, J. L., Dunand, J. P., and Pastouret, L., 1976. Résultats de dragages et essai de stratigraphie des bancs de Galice et des montagnes de Porto et de Vigo (Marge occidentale ibérique), Marine Geol., v. 22, p. M 37-M 49.

Dupeuble, P. A., Boillot, G., Lamboy, M., Malod, J., Mauffret, A., and Mougenot, D., 1977. Le passage JurassiqueCrétacé sur la marge continentale atlantique de la Péninsule Ibérique, Fifth réunion, Sci. Terre, Rennes, p. 210.

Durand-Delga, M., 1973. Les Calpionelles du Golfe de Gascogne, témoins de l'ouverture de l'Atlantique Nord, Soc. Géol. Fr. Bull., v. 15, p. 22-24.

Funnel, B. M. and Smith, A. G., 1968. Opening of the Atlantic Ocean, Nature, v. 219, p. 1328-1333.

Groupe Galice, Jonquet, H., and Williams, C., 1976. Les anomalies magnétiques du champ terrestre dans la région des bancs de Galice, Fourth réunion, Sci. Terre, Paris, p. 181.

Grunau, H. R., Lehner, P., Cleintuar, H. R., Allenbach, P., and Bakker, G., 1975. New radiometric ages and seismic data from Fuerteventura, Maio and São Tome, In Progress in geodynamics: Amsterdam (Roy. Neth. Acad. Art and Sci.), p. 90-118.

Hallam, A., 1971. Facies analysis of the Lias of West Central, Portugal, N. Yahrb. Geol. Pal., v. 139, p. 226-265.

Hayes, D. E. and Rabinowitz, P. D., 1975. Mesozoic magnetic lineations and the magnetic quiet zone off Northwest Africa, Earth Planet. Sci. Lett., v. 28, p. 105-115.

Hays, J. D. and Pitman, W. C., III, 1973. Lithospheric plate motion, sea level changes and climatic and ecological consequences, Nature, v. 246, p. 18-22.

Jansa, L. F. and Wade, J., 1975. Geology of the continental margin off Nova Scotia and Newfoundland. Offshore Geology of Eastern Canada, Geol. Surv. Canada, Paper 74-30, v. 2, p. 51-105.

Lamboy, M., 1976. Geologie marine et sous-marine du plateau continental au nord-ouest de l'Espagne. Genèse des glauconies et des phosphorites, Thèse d'état, Rouen, France.

Lamboy, M. and Dupeuble, P. A., 1975. Carte géologique du plateau continental nord-ouest espagnol entre le canyon d'Aviles et la frontière portugaise, Soc. Géol. Fr. Bull., v. 17, p. 442-461.

Larson, R. L., Pitman, W. C., III, 1972. World-wide correlation of Mesozoic magnetic anomalies and its implications, Geol. Soc. Am. Bull., v. 83, p. 3645-3662.

Laughton, A. S. and Berggren, W. A., et al., 1972. Shipboard reports of Sites 112, 118 and 119. In Laughton, A. S., Berggren, W. A., et al., Initial Reports of the Deep Sea Drilling Project, v. 12: Washington (U.S. Government Printing Office), p. 161-253 and 673-901.

Laughton, A. S., Roberts, D. G., and Graves, R., 1975. Bathymetry of the northeast Atlantic: Mid-Atlantic Ridge to southwest Europe, Deep-Sea Res., v. 22, p. 791-810.

Le Pichon, X. and Sibuet, J. C., 1971a. Comments on the evolution of the North-East Atlantic, Nature, v. 233, p. 257-258.

$1971 \mathrm{~b}$. Western extension of boundary between European and Iberian plates during the Pyrenean orogeny, Earth Planet. Sci. Lett., v. 12, p. 83-88.

Le Pichon, X., Sibuet, J. C., and Francheteau, J., 1977. The fit of continents around the North Atlantic Ocean, Tectonophysics, v. 38, p. 169-209.
Montadert, L. and Winnock, E., 1971. L'Histoire structurale du Golfe de Gascogne. In Histoire structurale du Golfe de Gascogne, a symposium: Paris (Technip), v. 2, Ch. VI-16.

Montadert, L., Damotte, B., Debyser, J., Fail, J. P., Delteil, J. R., and Valéry, P., 1970. Continental margin in the Bay of Biscay. In The Geology of the East Atlantic continental margin: ICSU-SCOR Working Party 31, Symposium, Cambridge 1970. Report 70-15, I.G.S., 1971.

Montadert, L., Damotte, B., Fail, J. P., Delteil, J. R., and Valéry, P., 1971. Structure géologique de la plaine abyssale du Golfe de Gascogne. In Histoire structurale du Golfe de Gascogne, a symposium: Paris (Technip), v. 2, Ch. XI-14.

Montadert, L., Winnock, E., Delteil, J. R., and Grau, G., 1974. Continental Margins of Galicia-Portugal and Bay of Biscay. In Burk, C. A., Drake, C. L. (Eds.), The Geology of Continental Margins: New York (Springer-Verlag), p. 323-342.

Mougenot, D., 1976. Géologie du plateau continental portugais (entre le Cap Carvoeiro et le Cap de Sines), Théese 3ème cycle, Université de Rennes, France.

Mouterde, R., 1971. Le Jurassique du Portugal. Esquisse stratigraphique et zonale, Soc. Geol. Portugal Bull., v. 18, p. 73-104.

Mouterde, R. and Ruget, C., 1975. Esquisse de la paléogéographie du Jurassique inférieur et moyen au Portugal. Soc. Géol. Fr. Bull., v. 17, p. 779-786.

Musellec, P., 1974. Géologie du plateau continental portugais au Nord du Cap Carvoeiro, Thèse 3ème cycle, Université de Rennes, France.

Olivet, J. L., Pastouret, L., Auzende, J. M., and Auffret, G., 1976a. Armorican margin evolution on relation with the Bay of Biscay genesis, Coll. IUSGS Durham, April 1976.

Olivet, J. L., Bonnin, J., and Auzende, J. M., 1976b. Manifestation des phases de compression tertiaire dans l'Atlantique du Nord-est, Fourth réunion, Sci. Terre, Paris, p. 311.

Parga, J. R., 1969. Sistemas de fracturas tardihercínicas del macizo hesperico, Trabajos Lab. Geol. de Lage, v. 37, p. 1-5.

Pastouret, L., Masse, J. P., Philip, J., and Auffret, G. A., 1974. Découverte de Rudistes d'âge Crétacé inférieur sur la marge armoricaine-implications paléogéographiques. Second réunion ann. Sci. Terre, Pont-à-Mousson. Soc. Geol. Fr. Spec. Summary.

Pautot, G., Auzende, J. M., and Le Pichon, X., 1970. Continuous deep-sea salt layer along north-Atlantic margins related to early phase of rifting. Nature, v. 227, p. 351-354.

Rabinowitz, P. D., Cande, S. C., and Hayes, D. E., in press. The $J$ Anomaly in the Central North Atlantic Ocean. Initial Reports of the Deep Sea Drilling Project, v. 43: Washington (U.S. Government Printing Office), p. 879-886.

Pitman, W. C. III, and Talwani, N., 1972. Sea-floor spreading in the North Atlantic. Geol. Soc. Am. Bull., 83, p. 619646.

Ramalho, M. and Rey, J., 1975. Etat des connaissances actuelles sur le Jurassique et le Crétacé basal du Portugal. Mém. Bur. Rech. Géol. et Minières., Fr., n. 86, p. 265-275.

Rey, J., 1972. Etude stratigraphique du Jurassique supérieur et du Crétacé inférieur de la région de Lisbonne, Thèse d'état, Université de Toulouse.

Ruget-Perrot, C., 1961. Etudes stratigraphiques sur le Dogger et le Malm inférieur du Portugal au Nord du Tage, Mem. Serv. Geol. Portugal, no. 7, p. 195.

Schlee, J., Behrendt, J. L., Grow, J. A., Robb, J. M., Mattick, R. E., Taylor, P. T., and Lawson, B. J., 1976. Regional geologic framework off northeastern United States, Am. Assoc. Petrol. Geol. Bull., no. 60, p. 926-951. 
Sherwin, D. F., 1973. Scotian shelf and GFand Banks. In Grossan, M. (Ed.), The future petroleum provinces of Canada: Can. Soc. Petrol. Geol., p. 519-559.

Sibuet, J. C. and Le Pichon, X., 1971. Structure gravimétrique du Golfe de Gascogne et fossé marginal nord-espagnol. In Histoire structurale du Golfe de Gascogne, a symposium: Paris (Technip), v. 2, Ch. VI-9.

Sibuet, J. C., Pautot, G., and Le Pichon, X., 1971. Interprétation structurale du Golfe de Gascogne à partir des profils de sismique. In Histoire structurale du Golfe de Gascogne, a symposium: Paris (Technip), v. 2, Ch. VI-10.

Teixera, C., 1968. Quelques problèmes de la géologie du Portugal, 23rd Geol. Congress, Prague, v. 13, p. 133-242.

van Hinte, J. E., 1976. A Cretaceous time scale, Am. Assoc. Petrol. Geol. Bull., no. 60, p. 498-516.
Van Houten, F. B., 1977. Triassic-Liassic deposits of Morocco and Eastern North America, Am. Assoc. Petrol. Geol. Bull., no. 61, p. 79-99.

Vegas, R., 1975. Wrench-(Transcurrent) fault system of the Southwestern Iberian Peninsula, Paleogeographic and morpho-structural implications, Geol. Rundschau, v. 64, p. 266-278.

Wilson, R. C. L., 1975. Atlantic opening and Mesozoic Continental Margin basins of Iberia, Earth Planet. Sci. Lett., v. 25 , p. $33-43$.

Winnock, E., Fried, E., and Kieken, M., 1973. Les caractéristiques des sillons aquitains, Bull. Soc. Géol. Fr., v. 15, p. 51-60.

Ziegler, W. H., 1975. Outline of geological history of North Sea. In Woodland, A. W. (Ed.), Petroleum and the Continental shelf of North West Europe, Geology, v. 1. 